ARH-ST- 118 B

$\mathrm{UC}-4, \mathrm{UC}-70$

\title{
ATLANTIC RICHFIELD HANFORD COMPANY \\ SEMIANNUAL REPORT \\ BB PROCESS DEVELOPMENT \\ MAY 1, 1974 THROUGH OCTOBER 31, 1974
}

\author{
Edited by \\ R. D. Fox \\ Research Department \\ Research and Engineering Division
}

\section{January 1975}

NOTICE

This report was prepared as an account of work sponsored by the United States Government. Neither sponsored by the United the United States Energy the United States nor the United States Enery Research and Development Admin contractors, their employees, nor any of their contractors, subcontractors, or their employes, makes any warranty, express or implied, or assumes any leteness liability or responsibility for the accuracy, completeness or usefulness of any information, apparatus, product or process disclosed, or represents

ATLANTIC RICHFIELD HANFORD COMPANY RICHLAND, WASHINGTON 99352

ЭISTRIBUTION OF THIS DOCUMENT UNLIMITED

FIRST UIRESTRICTED JUN 


\section{DISCLAIMER}

This report was prepared as an account of work sponsored by an agency of the United States Government. Neither the United States Government nor any agency Thereof, nor any of their employees, makes any warranty, express or implied, or assumes any legal liability or responsibility for the accuracy, completeness, or usefulness of any information, apparatus, product, or process disclosed, or represents that its use would not infringe privately owned rights. Reference herein to any specific commercial product, process, or service by trade name, trademark, manufacturer, or otherwise does not necessarily constitute or imply its endorsement, recommendation, or favoring by the United States Government or any agency thereof. The views and opinions of authors expressed herein do not necessarily state or reflect those of the United States Government or any agency thereof. 


\section{DISCLAIMER}

Portions of this document may be illegible in electronic image products. Images are produced from the best available original document. 


\section{TABLE OF CONTENTS}

$\underline{\text { Page }}$

ABSTRACT . . . . . . . . . . . . . . . . . . . . . .

INTRODUCTION . . . . . . . . . . . . . . . . . . . . . . . . . . . . . . .

SUMMARIES AND MILESTONES . . . . . . . . . . . . . . . . . 2

PLUTONIUM PRODUCTION . . . . . . . . . . . . . . . . . . . 10

PLUTONIUM SCRAP PROCESSING . . . . . . . . . . 10

Plutonium Oxide Dissolution . . . . . . . 10

Leaching Plutonium from Soil. . . . . . . 12

Fused Salt Alternatives . . . . . . . . . 14

Radiolysis-Resistant Solvent . . . . . . . 16

Amine Solvent Extraction of Plutonium . . . 18

Bidentate organophosphorus Extraction of
Americium and Plutonium . . . . . . . . . 20

Disposal of Waste Organic solvents. . . . 23

WASTE MANAgement . . . . . . . . . . . . . . . . . . . 25

SOLIDIFICATION AND ENCAPSULATION • • • • • • • 25

Concentration of Nonboiling wastes. . . . 25

Removal of Nonpumpable Tank Liquors . . . . 28

Wiped Film Evaporation of Residual Liquor . 30

Solidification by the Aqueous Silicate

Process . . . . . . . . . . . . 32

Characterization of Waste Tank Salt Cake . . 36

PUBLIC PROTECTION ASSURANCE . . . . . . . . . 39

Waste Cleanup and/or Immobilization . . . 39

Nondestructive Measurement Instrumentation . 43

Environmental Instrumentation . . . . . . 46

Waste Characterization . . . . . . . . 51

WASTE TANK LEAK DETECTION AND PREVENTION • • • 57

Wastè Tank Liquid Level Monitoring Systems . 57

Waste Tank Integrity . . . . . . . . . . 60

External Leak Detection . . . . . . . . 64 


\section{ABSTRACT}

This document represents the second in a series of documents which wizl report on a semiannual basis the activities supported by $B B$ Process Development funds. These research and development activities have the goal of improving the performance of the plutonium processing and waste management programs being operated by the Atrantic Richfiezd Hanford Company. 


\section{ATLANTIC RICHFIELD HANFORD COMPANY SEMIANNUAL REPORT \\ BB PROCESS DEVELOPMENT \\ MAY 1, 1974 THROUGH OCTOBER 31, 1974}

\section{INTRODUCTION}

This document describes the scientific investigations currently being sponsored by $B B$ process development funds under the direction of Atlantic Richfield Hanford Company's Research and Engineering Division. The document has been divided into two categories--those associated with plutonium production and those associated with managing the wastes generated during production. Within these categories are specific areas of endeavor which have been described in 189's (a budget and planning device used to identify areas of interest which support Energy Research and Development Administration objectives). These 189's are further broken down into programs with progress identified in the semiannual Report.

Each program report is presented so that sufficient background is available to understand the reason for the program, what had transpired, a review of the current progress, and, finally, identification of the current direction. At the beginning of the report is a brief on each program which consists of a summary, current accomplished milestone, and milestones for the next report period. 


\section{SUMMARIES AND MILESTONES}

$\underline{\text { Page }}$

\section{PLUTONIUM PRODUCTION}

\section{PLUTONIUM PROCESSING}

Plutonium Oxide Dissolution

Rate constants for $\mathrm{PuO}_{2}$ dissolution in nitrichydrofluoric acid mixtures have been calculated over the temperature range $35^{\circ}$ to $100^{\circ} \mathrm{C}$.

Milestone: Rate constants have been calculated for all dissolution experiments.

Milestone for Next Period: A final report will be prepared and issued.

Leaching Plutonium from Soil

Plutonium in Z-9 Enclosed Trench soil is concentrated in particles of sand with diameters of 100 micrometers or less. Operating parameters for leaching plutonium from $\mathrm{Z}-9$ Trench fines with $12 \mathrm{M} \mathrm{HNO} 3-0.5 \mathrm{MF}$ were investigated; 90 to $95 \%$ was the normal decontamination. The improved process of $\mathrm{HCl}_{-S \mathrm{Cl}_{2}-\mathrm{HF}}$ was tested.

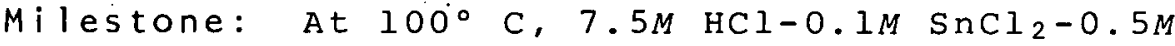 HF leachant removes more than $99 \%$ of the plutonium from the fines. \\ Milestone for Next Period: Process prototype equipment for soil processing will be designed and tested.}

\section{Fused Salt Alternatives}

Fusion tests were made using incinerator ash, leached incinerator ash, and centrifuged solids. Plutonium recoveries from the fused salt-plutonium scrap matrix ranged from 2 to $97 \%$ depending on the plutonium scrap and the ratio of salt-to-scrap used during fusion.

Milestone: Plutonium recovery tests have been completed with acid-leached ash and process salts. 
Milestone for Next Period: Evaluation of data and feasibility studies for processing will be completed.

Radiolysis-Resistant Solvents

Trichlorobenzene (TCB) was successfully used as a diluent for Amberlite LA- $2(\mathbb{B}$ (Rohm and Haas Company) in laboratory tests.

Milestone: Distribution data for use of $T C B$ diluent in the plutonium Reclamation Facility and the waste treatment systems flowsheet design were generated.

Milestone for Next .Period: Plutonium Reclamation Facility and waste treatment systems flowsheets using TCB will be optimized and tested in laboratory mixer-settler runs.

Amine Solvent Extraction of Plutonium

The amine process appears particularly weli suited for use with plutonium scrap containing significant concentrations of $240 \mathrm{Pu}$ and $241 \mathrm{Pu}$.

Milestone: Comprehensive data for equilibrium distribution of plutonium and nitric acid between $\mathrm{HNO}_{3}-\mathrm{Al}\left(\mathrm{NO}_{3}\right)_{3}-\mathrm{HF}$ solutions and $30 \%$ $\mathrm{LA}-2-\mathrm{CCl}_{4}$ solvent were obtained.

Milestone for Next Period: Methods of assem-. bling and correlating plutonium extraction data for computer-assisted flowsheets will be tested.

Bidentate Organophosphorus Extraction of Americium and Plutonium

Plutonium and americium were recovered from CAW solutions with as-received dibutyl $-\mathrm{N}, \mathrm{N}-$ diethylcarbamylmethylene phosphonate (DBDECMP). Iaboratory tests with dihexyl-N,Ndiethylcarbamylmethylene phosphonate (DHDECMP) were conducted. 


\author{
Milestone: A report describing laboratory tests \\ with DHDECMP extractants was prepared. \\ Milestone for Next Period: Suitability of as- \\ received DBDECMP for use in Am-Pu extrac- \\ tion, processes will be evaluated. \\ Disposal of Waste organic solvent
}

Routing of spent Plutonium Reclamation Facility solvents (TBP-DBBP-CCl 4 ) to the 242-T Evaporator was investigated as a viable disposal method for waste organic material:

Milestone: Laboratory-scale evaluations were completed on the feasibility and safety in disposing of waste organic material.

Milestone for Next.Period: Similar disposal methods will be considered for other organic solvent wastes.

\title{
WASTE MANAGEMENT
}

\section{SOLIDIFICATION AND ENCAPSULATION}

Concentration of Nonboiling wastes

Nondeliquescent solids from which. interstitial liquor can be readily drained are produced in a vacuum evaporator-crystallizer when the temperature of the evaporator is held below $60^{\circ} \mathrm{C}$ at 41 torr.

Milestone: Maximum temperature for the production of nondeliquescent, drainable salt in the vacuum-crystallizer was experimentally identified.

Milestone for Next Period: Physical and chemical characteristics of a variety of projected solidified terminal liquors will be established. 
Carbon dioxide reacts with sodium hydroxide in damp salt cake, changing its, characteristics. Techniques for reducing the hygroscopicity of the salt cake were investigated.

Milestone: The hygroscopicity of a salt cake was reduced by flooding with carbon dioxide.

Milestone for Next Period: Means of displacing or solidifying nonpumpable liquors will be tested.

Wiped Film Evaporation of Residual Liquor

The wiped film evaporator test.unit was fabricated and operated to determine its ability to reduce the water content of terminal residual liquor. The unit was tested in the laboratory using a range of feed rates and steam pressures.

Milestone: Feasibility studies for the unit were completed ahead of schedule.

Milestone for Next Period: Program completed.

Solidification by the Aqueous silicate process

Cancrinite products obtained by reaction of clays with synthetic terminal liquor were tested for radiolytic stability, heat of formation, rate of formation, leach rate, and mechanical strength.

Milestone: Radiation stability, heat of formation, rate of formation, leach rates, and mechanical, strength of aqueous silicate products were determined.

Milestone for Next Period: The use of portland cement as a binder for washed cancrinite crystals in the Aqueous Silicate process will be evaluated. 
Salt cakes and sludges from selected waste tanks have been partially characterized.

Milestone: Salt cakes from the 242-S Evaporator slurry receiving tanks have been analyzed. Thermal conductivity measurements have been made on salt and sludge samples from selected tanks.

Milestone for Next Period: A procedure will be completed for analyzing plutonium in salt cake. Salt from the 242-s Evaporator will be analyzed as it becomes available.

\section{PUBLIC PROTECTION ASSURANCE}

Waste Cleanup and/or Immobilization.

A water spray system was designed and testing initiated on sock filter efficiency in the mobile vacuum cleaner prototypé system. A 16 cubic yard vacuum system from Power Masters of Portland, Oregon, was tested on the BC Crib area. Laboratory simulations of field well-grouting and soil stabilization were conducted using asphalt, asphalt-cement, and cement with soil mixtures. Simulated high-level waste affixation studies were made made using asphaltic suspensions.

scope flowsheets were devised and discussions held. with offsite vendors concerning in-place pond bottom cleanup.

Milestone: Tests with mobile vacuum systems for cleanup of surficial radioactive contamination showed the feasibility of surface soil removal. The distribution of particle sizes in $U$ Pond bottoms was determined. Further testing was deferred due to reduction of project priority levels.

Milestone for. Next Period: A "cold" field test for affixing subsurface contamination will be initiated. "Cold" pond bottom removal tests will be completed. 
The GXDR (Gamma, X-Ray Data Reduction) system has successfulìy demonstrated it $\bar{s}$ ability to perform active data reduction for six satellite acquisition systems and to temporarily retire six pulse height analyzers and a data reduction system.

Milestone: The GXDR system was placed in operation. A failed intermediate activity detector system was replaced and calibrated.

Milestone for Next Period: A report on the use of the ARIS-2 (Automatic Radioactive Inventory system) for gamma añalysis in the GXDR system will be issued. The four ND50/50 analyzers will be converted to operation of GXDR satellite analyzers.

Environmental Instrumentation

Dev-Van-I was received and design of auxiliaries and in-van instrumentation was initiated. Some of the instrumentation for Dev-Van-I was calibrated and field-tested. An alpha water meter capable of detecting less than $M P C_{W}$ for $P u$ was calibrated; gamma, neutron; and directional neutron detectors were further developed and some were field-tested. A wafer technique for profiling plutonium in regions of high-gamma activity was tried in a plutonium crib and a high-level waste tank.

Milestone: A paper entitled "Directional Neutron Flux Survey of Actinide waste Trench", ARH-SA-184, was prepared and the abstract appeared in $A N S$ Transactions, Vol. 18.

Milestone for Next Period: Initial testing of a ${ }^{90} \mathrm{Sr}$ beta assayer will begin and a status report will be issued. Two National Nuclear Corporation experimental instruments will be tested for the Atlantic Richfield Hanford Company. 
studies continued on waste characterization involving environmental sampling, sample preparation, and environmental analysis. An interlaboratory analysis reliability program was initiated. About 200 more environmental analyses were obtained on U Pond, BC Crib, and Redox Swamp-Ditch. - Resuspension data were obtained for. $B C$ Crib and $U$ Pond. Twenty-five detonation experiments on simulated highlevel salt cake-anion exchange resin mixtures were conducted at stanford Research Institute.

Milestone: A paper, ARH-SA-184, was issued (see "Environmental Instrumentation") which describes the neutron characterization of the z-9 Enclosed Trench by specially developed directional neutron counters. A report on. the toxicity of the elements was issued.

Milestone for Next Period: A document on dust devils and anomalous winds and reports on resuspension and telemetering will be issued.

WASTE TANK LEAK DETECTION AND PREVENTION

Waste Tank Liquid-Level Monitoring systems

In a search for improved means of determining liquid levels in radioactive waste storage tanks, diverse methods of monitoring liquid level were investigated and a radiofrequency absorption-type and an ultrasonic log concept were selected for further study. Both systems were demonstrated in the laboratory.

Milestone: Installation of instrumentation for field-tests of both systems was completed.

Milestone for Next Period: Both systems will be field-operable and providing data by March 1975 . 


\begin{abstract}
Waste Tank Integrity
Electronic components have been assembled for fieldtesting of the ultrasonic probe which will be used to inspect the mild-steel liners of waste tanks for corrosion.
\end{abstract}

$\underline{\text { Page }}$ 60

Milestone: Assembly of electronic components - was completed on schedule. Further development work has been temporarily suspended due to budgetary restraints.

Milestone for Next Period: Corrosion probes: will be installed in waste tanks by April 1975 .

External Leak Detection

Gamma detector, soil conductivity, and soil impedance systems are being investigated to provide earlier detection of small leaks in waste tanks. The soil conductivity system was field-tested as was the soil impedance system which showed the resistance between tanks and wells to be an order of magnitude lower than observed in tank leak simulation tests.

Milestone: A single tank soil conductance test and initial Tank Farm soil impedance tests were completed.

Milestone for Next Period: The system which is deemed to be the most suitable will be tested on a larger scale by June 1975 . 


\section{PLUTONIUM PRODUCTION}

\section{PLUTONIUM SCRAP PROCESSING}

Plutonium Oxide Dissolution

$\begin{array}{ll}\text { Project Managers: } & \text { H. Babad } \\ & \text { N. L. Harms } \\ \text { Principal Investigator: } & \text { G. S. Barney }\end{array}$

Objective and Scope

This work will furnish a better understanding of the dissolution behavior of plutonium dioxide $\left(\mathrm{PuO}_{2}\right)$ in nitric-hydrofluoric acid mixtures--knowledge which will be used to improve the recovery of plutonium from scrap.

\section{Prior Work}

A rate law describing the dissolution of powdered $\mathrm{PuO}_{2}$ in nitric-hydrofluoric acid mixtures, which can be applied over the entire range of dissolution, is given by the equation

$$
\frac{d[P u]_{t}}{d t}=k_{1} S[H F]_{t}
$$

where $K_{1}$ is the rate constant, $S$ is the surface area of the $\mathrm{PuO}_{2},[\mathrm{HF}]_{f}$ is the concentration of free (noncomplexed) hydrofluoric acid, and [Pu]t is the total plutonium concentration (complexed and noncomplexed). This rate law implies. a dissolution mechanism in which the rate-controlling step is attack of the $\mathrm{PuO}_{2}$ surface by undissociated $\mathrm{HF}$. The rapid decrease in dissolution rate with time is due to the removal of free $\mathrm{HF}$ from solution through the formation of $\mathrm{PuF}_{4}(4-x)+$ complexes as the $\mathrm{PuO}_{2}$ is dissolved. The use of concentrated $\mathrm{HNO}_{3}(15.8 \mathrm{M})$ increases the dissolution rate significantly as compared with the $12 \mathrm{M} \mathrm{HNO}_{3}$ presently used in the plant. 


\section{Progress During Report Period}

Rate constants for $\mathrm{PuO}_{2}$ dissolution at $35^{\circ}, 4^{\circ}$, $55^{\circ}, 75^{\circ}$, and $100^{\circ} \mathrm{C}$ have been calculated for the rate law.

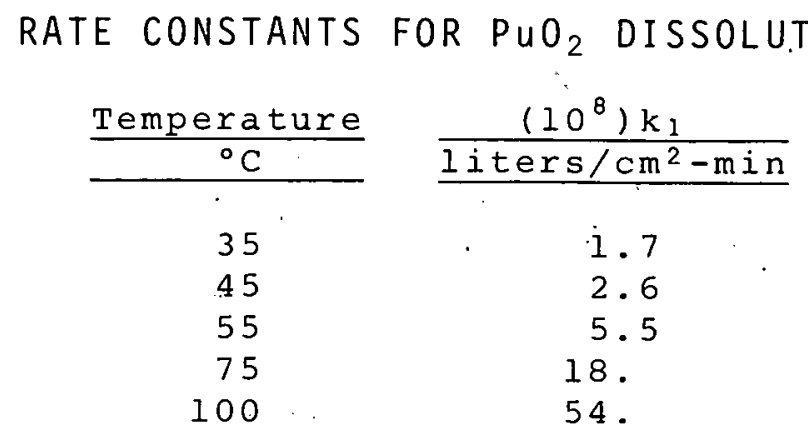

At $\mathrm{HNO}_{3}$ concentrations greater than $\sim 8 M$ the only significant fluoride complex present is $\mathrm{PuF}^{3+}$. From equilibrium and mass balance relationships, the concentration of noncomplexed hydrofluoric acid $[\mathrm{HF}]_{\mathrm{f}}$, is

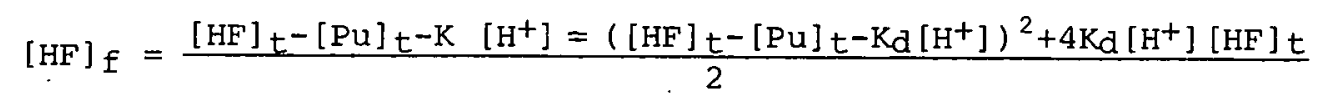

where $[\mathrm{HF}]_{t}$ is the total concentration of $\mathrm{HF}$, and $\mathrm{K}_{\mathrm{d}}$ is the dissociation constant for $\mathrm{PuF}^{3+}$. Values for $\mathrm{K}_{\mathrm{d}}$ calculated from the rate data. averaged $2.0 \times 10^{-4} \mathrm{M}$. The effect of temperature on $\mathrm{K}_{\mathrm{d}}$ over the range $35^{\circ}$ to $100^{\circ} \mathrm{C}$ was smaller than the experimental error.

\section{Evaluation of Effort}

A rate law and mechanism for the complete range of dissolution conditions have been obtained. These show the importance of maintaining high concentrations of free (noncomplexed) $\mathrm{HF}$ and $\mathrm{HNO}_{3}$ in order to speed the dissolution. Rate constants have been evaluated over the range of temperatures $35^{\circ}$ to $100^{\circ} \mathrm{C}$. This information will provide a basis for correctly designing dissolution flowsheets. 


\section{Future Work}

No additional experimental work is planned. A report summarizing this work will be prepared.

Leaching Plutonium from soil

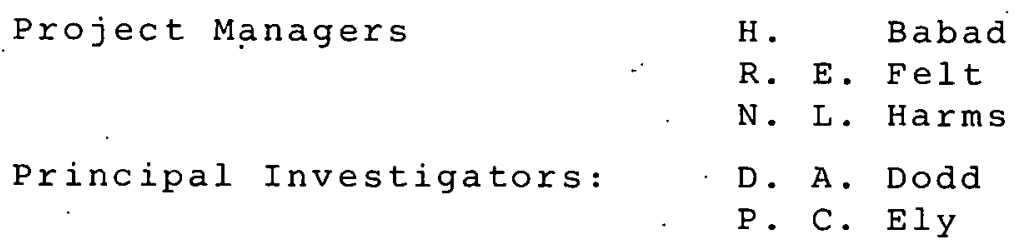

\section{Objective and scope}

The objective of this study is to provide data for future flowsheet development which will be used to reclaim plutonium from the z-9 Enclosed Trench soil for site restoration.

\section{$\underline{\text { Prior Work }}$}

Studies indicate that plutonium is concentrated in the top 15 centimeters of the Trench as particulate oxide, tightly bound ion-exchanged species, and material adsorbed in cracks and fissures of the sand.

Tests have shown that screening with $6 \mathrm{M} \mathrm{HNO}_{3}$ separates the fines containing about $90 \%$ of the plutonium and pretreats the particulates for ensuing dissolution and leaching techniques.

\section{Progress During Report Period}

Leaching and dissolution test's were conducted with solvents in the rainge of $12 \mathrm{M} \mathrm{HNO}_{3}-0.1 \mathrm{M} \mathrm{HF}$ to $12 \mathrm{M} \mathrm{HNO}_{3}-0.6 \mathrm{M}$ 
$\mathrm{HF}$ and solute-to-solvent ratios of 100 to $200 \mathrm{~g} / \mathrm{liter}$. The maximum leach results indicate that 90 to $95 \%$ of the plutonium is removed from the residual soil. Increasing the fluoride concentration above $0.2 M$ is detrimental to the efficient recovery of the plutonium.' The amount of plutonium removed by a second contact of the soil (one-hour reaction time) with a fresh portion of solvent was less by a factor of 10 than that removed by the initial contact.

A new procedure using $7.5 \mathrm{M} \mathrm{HCl}-0.1 M \mathrm{SnCl}_{2}-0.5 \mathrm{M} \mathrm{HF}$ as solvent was tested with very good results. After the fines were contacted for one hour with agitation at $90^{\circ} \mathrm{C}$, no detectable plutonium was found on the residual sand. Solute-to-solvent ratios were about $200 \mathrm{~g} / \mathrm{liter}$. The $\mathrm{HCl}$ system is not desirable for processing equipment now in place.

Budgetary constraints and higher priority development work limited investigation on this project.

\section{Evaluation of Effort}

The $\mathrm{HCl}-\mathrm{SnCl}_{2}-\mathrm{HF}$ process appears to be superior to the $\mathrm{HNO}_{3}-\mathrm{HF}$ techniques for removing plutonium from soils; however it is undesirable for processing systems now in place which are not constructed to contain chloride salts.

\section{Future Work}

Prototypical testing and conceptual design of processing equipment will continue for an $\mathrm{HNO}_{3}-\mathrm{HF}$ leaching system to provide technology for future plutonium recovery from the stored soil. 
Fused Salt Alternatives

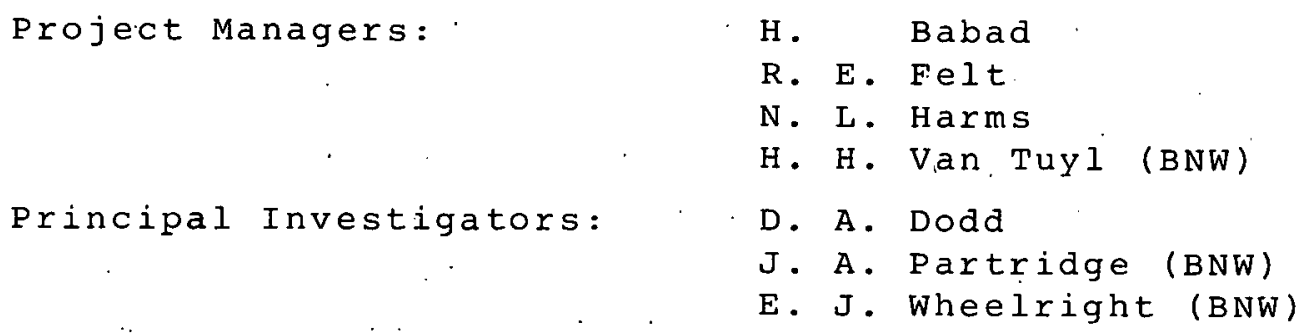
plutonium from existing incinerator ash, acid-leached ash, and process-collected solids; and (3) test the removal of $\mathrm{NO}_{2}$ from dissolver off-gas by means of hydroxylamine nitrate. The processes are to be demonstrated on a laboratory scale.

\section{Prior Work}

Two processes for decomposition of carbonaceous waste materials in molten salt systems, direct combustion with a supply of oxygen and pyrolysis in the absence of oxygen, have been investigated and satisfactorily demonstrated. At operating temperatures of $500^{\circ}$ to $800^{\circ} \mathrm{C}$ a $\mathrm{KNO}_{3}-\mathrm{NaNO}_{3}$ salt proved adequate as an oxidizing salt and $\mathrm{K}_{2} \mathrm{CO}_{3}-\mathrm{Li}_{2} \mathrm{CO}_{3}-\mathrm{NaNO}_{3}$ was found to be a complementary "inert" salt.

In tests using equal amounts (by weight) of $\mathrm{NaOH}-$ $\mathrm{Na}_{2} \mathrm{O}_{2}$ and regular incinerator ash-to-salt ratios as high as $2: 7$, plutonium recoveries of $95 \%$ or greater have been attained during a single contact. Recycling the residual solids completes the plutonium recovery. 
Under the same conditions, tests on a second can of incinerator ash recovered only $74 \%$ of the plutonium. At an ash-to-salt ratio of $1: 7$ the recovery was only $85 \%$.

Greater than 99\% removal of $\mathrm{NO}_{2}$ from air containing 12,000 parts per million $\mathrm{NO}_{2}$ was obtained at an air flow rate of $2,000 \mathrm{ml}$ per minute and an aqueous flow rate of one $\mathrm{ml}$ per minute. The superiority of an aqueous scrub solution of $0.4 \mathrm{M}$ hydroxylamine nitrate-0.90M $\mathrm{HNO}_{3}$ over $0.90 \mathrm{M} \mathrm{HNO}_{3}$ was demonstrated.

\section{Progress During Report Period}

Continued molten salt fusion tests on the second can of incinerator ash using equal weights of $\mathrm{NaOH}-\mathrm{Na}_{2} \mathrm{O}_{2}$ and an ash-to-salt ratio of $1: 7$ confirmed the lower plutonium recovery. When solids from previous fusions were recycled in the ash-to-salt ratio of $1: 7$. the plutonium solubilization was $89 \%$.

Gelatinous material which formed in the solution during acidification (not evident in previous tests) was one cause for low plutonium recovery. The entrained plutoniumbearing solution cannot adequately be separated from the gelatinous material. Although this gel has not been characterized, it is considered silica from the ash.

Fusions carried out with incinerator ash from a - third can more closely resembled tests with the first can, with plutonium recoveries of $91 \%$ when the ash-to-salt ratio was maintained at $2: 7$.

Four fusion tests were made on ash leached with the $\mathrm{HNO}_{3}-\mathrm{HF}$ dissolver plutonium. Plutonium recoveries ranged from $97 \%$ at an ash-to-salt ratio of $2: 7$ to $<2 \%$ at an ash-to-salt ratio of $1: 1$. 
Accumulated solids centrifuged from plant process streams during solvent extraction processing have been characterized as a sodium fluorosilicate with inconsistent composition. They have proven quite insoluble in $\mathrm{HNO}_{3}-\mathrm{HF}$ dissolver solution. In one-hour fusion tests using these process stream solids at a solids-to-salt ratio of $1: 7,89 \%$ of the plutonium was recovered; while at a solids-to-salt ratio of $1.3: 7^{\circ}$ the recovery dropped to $63 \%$. With a two-hour fusion time and at a solids-to-salt ratio of $2: 7$, the plutonium recovery was as high as $95 \%$.

\section{Evaluation of Effort}

This process allows recovery of plutonium from small volumes of scrap which is not recoverable by other modes of processing.

\section{Future Work}

Experimental data will be evaluated and processing applicability studies will be made.

Radiolysis-Resistant Solvent

$\begin{array}{ll}\text { Project Managers: } & \text { R. E. Felt } \\ & \text { H. } \\ & \text { Gabad } \\ \text { Principal Investigators: } & \text { G. Barney } \\ & \text { D. G. Bouse }\end{array}$

\section{Objective and Scope}

The purpose of this program is to develop a solvent composition for plutonium extraction that is more resistant to radiolysis than the presently used tributylphosphonate (TBP)-carbon tetrachloride $\left(\mathrm{CCl}_{4}\right)$ extractant. 


\section{Prior Work}

Relevant physical and chemical properties of pure aromatic halides and chloroethylene compounds and 20\% TBPdiluent mixtures were determined to evaluate their usefulness in extracting plutonium and americium. Of the diluents tested, trichlorobenzene (TCB) has the most acceptable physical properties for a heavy organic phase solvent extraction system. Flowsheet tests using TCB as a diluent for TBP demonstrated that workable flowsheets can be developed. The effect of nitrous acid on the radiolysis and hydrolysis of TBP was found to be negligible. Chemical degradation of TBP at room temperature was found to be insignificant compared with radiolytic degradation.

\section{Progress During Report Period}

Batch distribution coefficients were determined for plutonium and $\mathrm{H}^{+}$in the TBP-TCB system over a wide range of acid and plutonium concentrations. Batch distribution coefficients were also determined for plutonium, americium, and $\mathrm{H}^{+}$in the dibutylbutylphosphonate (DBBP)-TCB system.

\section{Evaluation of Effort}

Sufficient distribution data were generated to permit flowsheet design for the Plutonium Reclamation Facility (TBP-TCB) and the waste treatment (DBBP-TCB) systems.

\section{Future Work}

No additional laboratory work is planned. 
Amine Solvent Extraction of Plutonium
Project Managers:
R. E. Felt
Principal Investigators:
H. Babad
W. W. Schulz
D. G. Bouse

\section{Objective and scope}

The objective is to improve solvent extraction performance in the Plutonium Reclamation Facility while decreasing costs by developing an amine plutonium extraction process to replace the currently used TBP process.

\section{Prior Work}

A revised and simplified conceptual plutonium recovery process flowsheet was devised which employs Amberlite LA-2R (Rohm and Haas Company), a high-molecular weight secondary amine as the extractant. The new process involves operation of only the CA (extraction), CC (strip), and $\mathrm{CO}$ (solvent wash) Columns. An $\mathrm{HNO}_{3}-\mathrm{HF}$ solution is used in the solvent wash column to remove small amounts of plutonium which are not stripped in the CC Column.

This new amine extraction process was satisfactorily demonstrated in mixer-settler runs at $25^{\circ} \mathrm{C}$ employing both $30 \% \mathrm{LA}-2-\mathrm{CCl}_{4}$ and 30\% LA-2-TCB (trichlorobenzene) solvents. With the $30 \%$ LA-2-TCB solvent, process performance was significantly enhanced by operation at $50^{\circ} \mathrm{C}$ rather than at $25^{\circ} \mathrm{C}$. At $25^{\circ} \mathrm{C}, \mathrm{LA}-2$ solvents extracted $\mathrm{Pu}(\mathrm{IV})$ from $\mathrm{HNO}_{3}-\mathrm{Al}\left(\mathrm{NO}_{3}\right)_{3}$ solutions more slowly than did TBP extractants; at $50^{\circ} \mathrm{C}$, however, a $30 \% \mathrm{LA}-2-\mathrm{TCB}$ solvent extracted $\mathrm{Pu}(\mathrm{IV})$ about as quickly as TBP solvents did at $25^{\circ} \mathrm{C}$. Operation of the amine extraction process at $50^{\circ} \mathrm{C}$ with a $30 \% \mathrm{LA}-2-\mathrm{CCl}_{4}$ solvent is, of course, not practicable because of the high volatility of $\mathrm{CCl}_{4}$ at elevated temperature. 
Chemical and radiolytic stability of the LA-2 extractant under proposed flowsheet conditions is superior to that of the presently used $20 \% \mathrm{TBP}-\mathrm{CCl}_{4}$ solvent. For example, after exhaustive stripping with dilute $\mathrm{HNO}_{3}$ an irradiated LA-2 solvent retains only about $0.3 \mathrm{mg}$ Pu/liter for each watt-hour of absorbed energy, compared with retention of $56 \mathrm{mg} \mathrm{Pu} /$ liter by an irradiated, stripped 20\% TBP$\mathrm{CCl}_{4}$ solvent.

\section{Progress During Report Period}

Having demonstrated in laboratory studies the technical feasibility and operability of a reflux amine flowsheet, current emphasis is on obtaining more comprehensive data for the equilibrium distribution of plutonium, nitric acid, uranium, thorium, and various other impurities among $\mathrm{HNO}_{3}-\mathrm{Al}\left(\mathrm{NO}_{3}\right)_{3}-\mathrm{HF}$ solutions and a $30 \% \mathrm{LA}-2-\mathrm{CCl}_{4}$ solvent. These data will provide input. for mathematical modeling of the amine system and will allow computer-assisted design and testing (using the program SEPHIS) of optimum flowsheet conditions. During the report period all the needed equilibrium data were obtained for the distribution of plutonium and $\mathrm{HNO}_{3}$ between $30 \% \mathrm{LA}-2-\mathrm{CCl}_{4}$ solvent and aqueous 0.1 to $4.0 \mathrm{M} \mathrm{HNO}_{3}-0.0$ to $1.0 \mathrm{M} \mathrm{Al}\left(\mathrm{NO}_{3}\right)_{3}-0.0$ to $0.25 \mathrm{M}$ $\mathrm{HF}$ solution containing $1,10,30$, and $60 \mathrm{~g} / \mathrm{liter} \mathrm{Pu}$.

\section{Evaluation of Effort}

Batch and mixer-settler tests of the conceptual three-column reflux amine process have shown this to be a workable scheme for use in the Plutonium Reclamation Facility. The amine process appears particularly well suited for use with plutonium scrap containing significant concentrations of ${ }^{240} \mathrm{Pu}$ and ${ }^{241} \mathrm{Pu}$. Further research effort to complete development and testing of the amine extraction 
scheme is merited.

\section{Future Work}

Available plutonium and nitric acid distribution data will be correlated in a form suitable for use in computer-assisted amine flowsheet design and testing.

Equilibrium data for the distribution of uranium and thorium between $\mathrm{HNO}_{3}-\mathrm{Al}\left(\mathrm{NO}_{3}\right)_{3}-\mathrm{HF}-\mathrm{Pu}\left(\mathrm{NO}_{3}\right)_{4}$ aqueous solutions and $30 \%$ $\mathrm{LA}-2-\mathrm{CCl}_{4}$ solvent will be acquired. Physical properties (e.g., viscosity, specific gravity, etc:) of $\mathrm{LA}-2-\mathrm{CCl}_{4}$ solvents will also be determined.

Reports Issued

W. W. Schulz, D. G. Bouse, and M. J. Kupfer, "Reflux Amine Flowsheet for Plutonium Recovery from Metal"Iurgical Scrap," in Proceedings International Solvent Extraction Conference 1974, Vol. 3, Society of Chemical Industry, London, pp. 2035-2062.

Bidentate Organophosphorus Extraction of Americium and Plutonium

Project Managers:

Principal Investigators:
R. E. Felt

H. Babad

W. W. Schulz

D. G. Bouse

\section{Objective and Scope}

The principal objective of this task is to develop technology for reducing the actinide content of the Plutonium Reclamation Facility (PRF) aqueous waste stream to the 
$10 \mathrm{nCi} / \mathrm{g}$ level. A secondary objective is to develop a bidentate organophosphorus solvent extraction process to recover both americium and plutonium directly from PRF acid waste (CAW stream), thereby avoiding the $\mathrm{pH}$ adjustment step required by the present DBBP (dibutylbutylphosphonate) extraction scheme.

\section{$\underline{\text { Prior Work }}$}

In extensive laboratory work on the second objective of this task, comprehensive data on the equilibbrium distribution of americium, plutonium, $\mathrm{HNO}_{3}$, and various impurity metals (e.g., $\mathrm{Ca}^{2+}, \mathrm{Mg}^{2+}$, etc.) between various aqueous $\mathrm{HNO}_{3}-\mathrm{Al}\left(\mathrm{NO}_{3}\right)_{3}-\mathrm{HF}$ solutions and 30 vol\% DHDECMP-CCl solvent were obtained. A bidentate organosphosphorus extractant, DHDECMP is an acronym for dihexyl-N, Ndiethylcarbamylmethylene phosphate, available from the Wateree Chemical Company,. Lugoff, South Carolina. Suitable acid hydrolysis-caustic washing procedures were developed for purifying the as-received DHDECMP. Stability of the $30 \%$ DHDECMP extractant to alpha radiolysis was found to be excellent over the range of exposure expected in PRF application ( 2 to 10 watt-hours per liter). Effects of crosscontamination of DHDECMP solvents with mainline $20 \% \mathrm{TBP}-\mathrm{CCl}_{4}$ solvents were determined.

These efforts culminated in a conceptual chemical flowsheet which was successfully demonstrated in mixersettler tests with actual CAW solution as feed. The new flowsheet increased overall americium recovery to $>90 \%$ from the 60 to $80 \%$ obtained with the present DBBP flowsheet. Over $99 \%$ of the soluble plutonium in the CAW solution was recovered. 
Progress During Report Period

A major part of this period's effort was spent in documenting DHDECMP studies.

In addition, distribution tests were made with DBDECMP (dibutyl-N,N-diethylcarbamylmethylenephosphonate) and TAMDP (tetraamylmethylenediphosphonate), the analog of DHDECMP. These tests confirmed that as-received DBDECMP is pure enough so that it can be used directly or after only simple carbonate washing (DHDECMP must be purified before use). Tetraamylmethylenediphosphonate was also found to be sufficiently pure; however capacity of 30 to $40 \%$ TAMDP-CCl solvents to extract $\mathrm{Am}$ (III) from $\mathrm{HNO}_{3}$ solution is substantially less than that of $30 \%$ DHDECMP or DBDECMP solvents.

\section{Evaluation of Effort}

Flowsheets which employ bidentate organophosphorus extractants for removing americium and plutonium from acid CAW solution can provide substantially improved recovery of americium over that obtained with monodentate reagents and can also generate sodium-free wastes. Such wastes are potentially well-suited for either tail-end treatment to make them actinide-free $(<10 \mu \mathrm{Ci}$ alpha emitters/g) or for calcination. The need to purify as-received DHDECMP is a serious deterrent; however preliminary data suggest that DBDECMP is a satisfactory alternative.

\section{Future Work}

Americium extraction and stripping properties of a new supply of DBDECMP will be evaluated. If these properties are favorable, detailed distribution, solvent radiolysis, and mixer-settler runs will be performed with a $30 \%$ DBDECMP solvent. 


\section{Reports Issued}

W. W. Schulz, Bidentate organophosphorus Extraction of Americium and Plutonium from Hanford Plutonium Reclamation Facility Waste, ARH-SA-203, Atlantic Richfield Hanford Company, Richland, Washington, September 1974.

\section{Disposal of Waste Organic Solvents}

$\begin{array}{ll}\text { Project Managers: } & \text { H. Babad } \\ & \text { R. E. Felt } \\ & \text { D. G. Harlow } \\ & \text { N. L. Harms } \\ \text { Principal Investigators: } & \text { D. A. Danch } \\ & \text {.D. A. Dodd } \\ & \text { D. A. Puryear }\end{array}$

\section{Objective and scope}

Technology is being developed which will permit safe, economical disposal of spent Plutonium Reclamation Facility. tributylphosphate (TBP) and dibutylbutylphosphonatecarbon tetrachloride (DBBP-CCl${ }_{4}$ ) solvents.

\section{Prior Work}

Wet oxidation tests conducted by ZIMPRO, Inc., a subsidiary of Sterling Drugs, demonstrated the effectiveness of the Zimmerman Process in oxidizing undiluted TBP at $325^{\circ} \mathrm{C}$ and 2300 to $2400 \mathrm{psig}$. When $\mathrm{CCl}_{4}$ was included, however, rapid pressurization and incomplete oxidation occurred. The added costs of fractional distillation of the $\mathrm{CCl}_{4}$ and maintenance of a new waste stream and process are not considered practical.

An alternative disposal method was investigated in 
which the organic solvent is combined with a commercially available surfactant and emulsified with aqueous waste. The resultant mixture (97 vol\% aqueous-3\% organic) is routed through the 242-T In-Tank Solidification Evaporator.

\section{Progress During Report Period}

A commercial surfactant, Ethomid $0 / 15^{\circledR}$ (Armak Corporation) was found to provide emulsification and stability superior to that produced by other surfactants tested. The emulsion was easily re-formed after several months with agitation: Differential thermal analysis data indicate that the exothermic reactions take place in either the solution mixture or the evaporated sludge phase as temperatures between ambient and $800^{\circ} \mathrm{C}$.

Preliminary studies have been made in the use of nitric-sulfuric acid solutions to oxidize spent organic solvents; however this work. has been temporarily deferred in favor of higher priority projects.

\section{Evaluation of Effort}

Adding Ethomid 0/15 to the spent organic-aqueous waste system forms a satisfactory emulsion for the transfer of the waste to the evaporation facility. This process eliminates the need for significant capital outlays for facilities construction.

\section{Future Work}

As priorities permit, laboratory. studies will continue on alternative methods of oxidizing waste organic material. 


\section{WASTE MANAGEMENT}

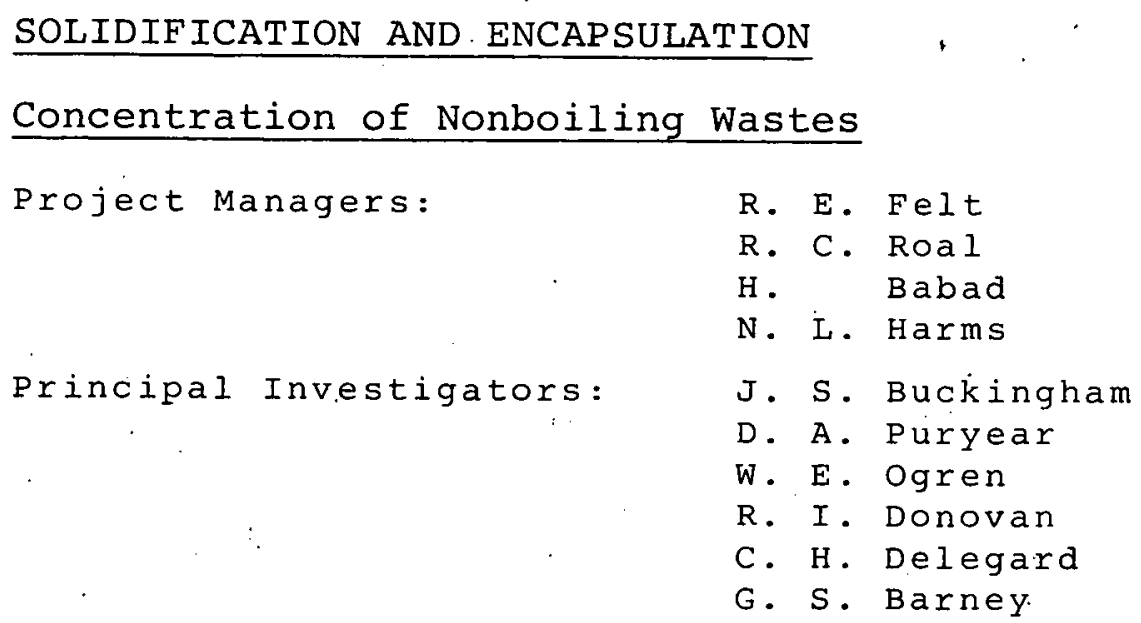

Objectives and Scope

The goal of this work is to define vacuum evaporator-crystallizer operating modes which will minimize the volume of recycle liquor remaining at the end of the waste solidification program. The salt cakes produced must be retrievable and storable for 10 to 100 years.

\section{$\underline{\text { Prior Work }}$}

During the concentration of nonboiling waste liquors in both atmospheric and vacuum evaporators, concentrations of $\mathrm{NaOH}$ and $\mathrm{NaAlO}_{2}$ increase until either the maximum possible concentration of the waste is reached or solids are produced which are not retrievable, contain interstitial liquid which cannot be pumped, or will deliquesce under storage conditions. Partial neutralization of recycle liquors with acids lowers their boiling points and thus permits additional concentration. Laboratory vacuum evaporator studies were made on partially neutralized synthetic recycle waste and compositions of slurries, liquors, and 
solids from various points in the waste concentrationsolidification cycle were determined.

Progress During Report Period

Sodium nitrate was found to be the principal solid phase produced by the vacuum evaporator at a temperature of less than $60^{\circ} \mathrm{C}$ and a pressure of 41 torr. The mother liquor was between 5 and $6 \mathrm{M} \mathrm{NaOH.} \mathrm{The} \mathrm{damp} \mathrm{salt} \mathrm{was} \mathrm{moder-}$ ately hygroscopic, deliquescing in about 20 days when placed in an $80 \%$ relative humidity cabinet at $23^{\circ} \mathrm{C}$. Meteorological conditions of this nature are rare at Hanford and are not anticipated to influence the storage of salt cake produced under these evaporator conditions. Increasing the evaporator temperature above $60^{\circ} \mathrm{C}$ increases the sodium hydroxide content of the solids to the point where they deliquesce at ambient conditions.

For further understanding of the phenomena which occur during evaporation of waste solutions, a correlation was made between nonvolatile residues (salts) and solution densities of liquid wastes. The data show that sodium nitrate precipitates out of supersaturated caustic waste solutions in the density range of 1.375 to $1.326 \mathrm{~g} / \mathrm{cc}$ at room temperature.

Partial neutralization of very caustic waste solutions (12M NaOH, similar to what might be found in terminal liquors) with up to 50 vol\% nitric acid gave a solution that could be evaporated to $\sim 80 \%$ of its original volume. The volume of solids formed by evaporation was $225 \%$ of the original solution and the volume of the mother liquor was $\sim 55 \%$ of the original solution.

When a caustic waste solution containing $0.9 \mathrm{M}$

(5.3\%) $\mathrm{NaAlO}_{2}, 1.4 \mathrm{M}$ (7.1\%) $\mathrm{NaNO}_{2}, 3.3 \mathrm{M}(20.5 \%) \mathrm{NaNO}_{3}$, and 
$5.5 \mathrm{M}$ (16\%) $\mathrm{NaOH}$ was evaporated in the pilot vacuum evaporator to $60^{\circ} \mathrm{C}$, two solid phases formed. The heavier solid contained $10 \%$ water, $2 \% \mathrm{NaAlO}_{2}, 78 \% \mathrm{NaNO}_{3}, 3 \% \mathrm{NaNO}_{2}$, and $6 \%$ $\mathrm{NaOH}$; while the lighter solid contained $14 \%$ water, $63 \%$ $\mathrm{NaAlO}_{2}, 11 \% \mathrm{NaNO}_{3}, 8 \% \mathrm{NaNO}_{2}$, and $4 \% \mathrm{NaOH}$. The volumes of the two solid phases were about the same. The mother liquor associated with the solid phases contained $0.4 \mathrm{M}$ (2\%) $\mathrm{NaAlO}_{2}$, $2.9 \mathrm{M}$ (16\%) $\mathrm{NaNO}_{3}, 2.6 \mathrm{M}$ (11\%) $\mathrm{NaNO}_{2}$, and $13.4 \mathrm{M}$ (35\%) $\mathrm{NaOH}$. The light, aluminum-rich solid phase was composed of very small particles which settled slowly and from which interstitial liquid would be difficult to remove.

Laboratory scouting runs were made on a process to remove sodium aluminate from waste solutions by reacting the aluminate with silica to form cancrinite.

The three sources of silica tested--bentonite, diatomite, and sodium silicate solution--all successfully removed aluminum from the waste solution. At $100^{\circ} \mathrm{C}$ reaction temperature, diatomite and sodium silicate removed more than $99 \%$ of the aluminum in 30 minutes, while bentonite removed $97 \%$ in 4 hours. The rate of aluminum removal decreased according to the order: sodium silicate>diatomite>bentonite. The cancrinite crystals formed by this process were very small and difficult to separate from the waste Iiquor.

Evaporation of a synthetic terminal liquor was demonstrated in Battelle Pacific Northwest Laboratories' pilot-scale wiped-film evaporator.' The machine adequately evaporated the caustic liquor. Higher operating temperatures resulted in more extensive evaporation and produced. slurries with as little as $26 \%$, water. The low water content products were fluid when discharged from the evaporator but solid at room temperature. 


\section{Evaluation of Effort}

Additional data were obtained which were useful in defining a mode of operation for the 242-S Evaporator for the production of "acceptable" salt product. Alternative operating modes for the vacuum evaporators have been explored and technical bases exist for their implementation, should the need arise.

\section{Future Work}

The chemical solidification of recycle liquor with arsenic trioxide will be tested. Additional partial neutralization work on laboratory and pilot-plant scales will be done both with and without aluminum removal.

Removal of Nonpumpable Tank Liqúors

$\begin{array}{ll}\text { Project Managers: } & \text { R. C. Roal } \\ & \text { H. Babad } \\ & \text { N. L. Harms } \\ & \text { R. E. Felt } \\ & \text { D. M. Strachan } \\ \text { Principal Investigators } & \text { J. S. Buckingham } \\ & \text { W. P. Metz } \\ & \text { J. C. Petrie } \\ & \text { D. R. Christianson }\end{array}$

Objective and Scope

The objective of this work is to explore, develop, and demonstrate methods for removal or in situ immobilization of liquids which lie below the designed pumping level of the waste tank pumps. In the largest tanks this liquid heel consists of approximately 120,000 liters of caustic, 
radionuclide-bearing liquids. These liquids might be displaced to a pumpabie level by use of a high-density organic liquid or moved by air jet to the pump. Alternatively, if the damp salt cake above the liquid level is dried, the nonpumpable liquid might be absorbed.

\section{Prior Work}

None.

\section{Progress During Report Period}

Extremely hygroscopic, damp solids from hightemperature runs of the pilot vacuum evaporator were placed in a $100 \%$ carbon dioxide atmosphere for 30 days. The reaction of the carbon dioxide with sodium hydroxide in the solid reduced the rate of water pickup but did not stop. deliquescence. In addition, the carbon dioxide did not form a layer of moisture-impervious sodium carbonate on the surface of the solid.

\section{Evaluation of Effort}

Initial laboratory work indicates that the carbon dioxide-sodium hydroxide reaction may be useful in changing the characteristics of salt cakes.

\section{Future Work}

Additional equipment for the program will be procured. Future plans call. for placement of liquors by injection of high-density organics mixed with surfactants; use of hot, dry carbon dioxide or carbon dioxide and nitrogen gas to dry the salt cake and react with the sodium hydroxide; and determination of the diffusion rate of carbon dioxide into the salt cake. 
Wiped-Film Evaporation of Residual Liquor

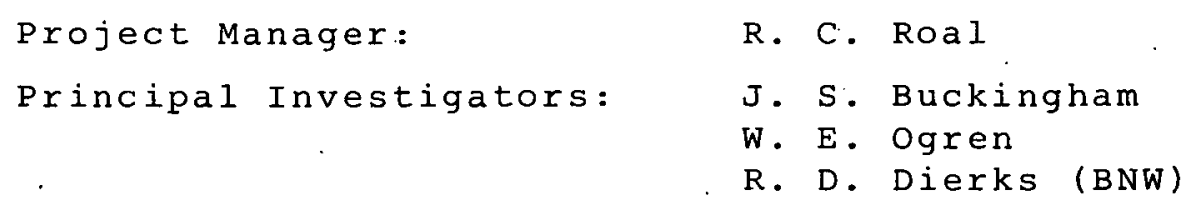

Objective and Scope

High-level liquid radioactive wastes at Hanford are currently being reduced in volume by repeated evaporation and fractional crystallization steps until little, if any, additional volume-reduction is effected, and a terminal residual liquor is encountered. The wiped-film evaporator is being evaluated to determine its applicability for obtaining additional volume reduction of the water content of the terminal residual liquor.

Prior work

Plans were completed for a preliminary test of the application of a wiped-film evaporator, and equipment was procured and installed. The evaporator is a horizontal unit with a tapered barrel I' $^{\prime}$ in diameter and has a 5-ft ${ }^{2}$ heat transfer surface heated with 120 psig steam. Adjustable paddles maintain a $1 / 32^{\prime \prime}$-thick film of material on the heat transfer surface.

\section{Progress During Report Period}

The liquid feed rate to the evaporator was between 15 and 60 liters per hour and the steam pressure to the heating jacket was varied from 30 to 120 psig: In all cases the product was a liquid. On cooling to ambient temperature, the visible free liquor varied from approximately 80 to 0 vol\% as the water content decreased from about 40 to 25 wt: The overall heat transfer coefficient for the unit 
ranged between 50 and $200 \mathrm{Bt}, \mathrm{hr}-{ }^{\circ} \mathrm{F}-\mathrm{ft}^{2}$ and was highly dependent on the solids content of the product as well as on the feed rate.

Additional experiments were conducted in which the feed. was a crystallizer slurry containing 43 wto water. At the maximum steam pressure the evaporator discharged a liquid product with a water content ranging from 25.7 to 29.1 wto which solidified on cooling. Overall heat transfer coefficients of $\sim 250 \mathrm{Btu} / \mathrm{hr}-{ }^{\circ} \mathrm{F}-\mathrm{ft}{ }^{2}$ were realized.

\section{Evaluation of Effort}

The tests described above indicate that the wipedfilm evaporator offers some possibilities as a useful tool for additional volume reduction of the terminal residual liquor remaining in the waste tanks.

Future Work

A few additional runs may be made to investigate the effect of feed composition and to determine the maximum: possible feed rate. 
Solidification by the Aqueous Silicate Process

$\begin{array}{ll}\text { Project Managers: } & \text { R. C. Roal } \\ & \text { H. Babad } \\ \text { Principal Investigators: } & \text { G. S. Barney } \\ & \text { C. H. Delegard } \\ & \text { W. P. Metz }\end{array}$

Objective and Scope

Using aqueous silicate chemistry, a process will be developed to solidify interstitial and recycle liquids from the evaporator-crystallizer program.

\section{Prior Work}

Reaction of synthetic recycle liquors from the evaporator-crystallizer program with various bentonite and kaolin clays produces the mineral cancrinite, a salt-filled sodium aluminum silicate. An appreciable amount of base ( $\mathrm{NaOH}$ or sodium aluminate $\left[\mathrm{NaAlO}_{2}\right]$ ) must be present in the waste for the reaction to occur. The amount of clay necessary to form a solid product varies from $0.70 \mathrm{~g} / \mathrm{ml}$ for spray-dried kaolin to $1.30 \mathrm{~g} / \mathrm{ml}$ for a conmercial bentonite. The product from kaolin is.harder than that from bentonite. The time necessary for the clay-waste reaction to go to completion is $23 \mathrm{hr}$ at $100^{\circ} \mathrm{C}$ and $212 \mathrm{hr}$ at $75^{\circ} \mathrm{C}$. Bulk leach rates for the products in distilled water based on B.E.T. (gas adsorption) surface area measurements are in the range $10^{-8}$ to $10^{-7} \mathrm{~g} / \mathrm{cm}^{2}$-day.

Cancrinite products from 39 commercially available clays were tested for hardness, $\mathrm{pH}$, volume increase, and percent liquid not sorbed by the product. Fourteen clays were chosen for further study. Thermal analyses of cancrinite products showed a loss of zeolitic water $\left(50^{\circ}\right.$ to $\left.300^{\circ} \mathrm{C}\right)$, crystalline transition to nepheline $\left(600^{\circ} \mathrm{C}\right)$, 
decomposition of nitrate and nitrite salts $\left(700^{\circ}\right.$ to $\left.900^{\circ} \mathrm{C}\right)$; and melting $\left(900^{\circ}\right.$ to $\left.1200^{\circ} \mathrm{C}\right)$. Cancrinite products made from reactions of synthetic 242-s Evaporator slurries with clays had physical properties almost identical to those obtained from synthetic recycle liquor.

\section{Progress During Report Period}

The radiolytic stabilities of various powdered silicate product (cancrinite) materials were determined in the irradiation test facilities at Westinghouse Hanford Company. Aqueous silicate products made from synthetic waste liquor and montmorillonite, kaolinite, calcined kaolinite, and a mixed kaolin-montmorillonite were subjected to approximately $9 \times 10^{8}$ rads of ${ }^{60} \mathrm{Co}$ radiation (a calculated upper limit anticipated for aqueous silicate products with an initial ${ }^{137} \mathrm{Cs}$ concentration of $1 \mathrm{Ci} / \mathrm{liter}$. Typical terminal liquors contained 0.3 to $0.5 \mathrm{Ci} / \mathrm{liter} \mathrm{X}$-Ray diffraction, scanning electron photomicrographs, and thermogravimetric studies comparing the irradiated and unirradiated samples showed no radiation-induced alteration of the structures of the tested materials.

The heat of reacton of calcined and uncalcined kaolin (Georgia Kaolin Astra-Glaze $\left.{ }^{(\mathcal{B}}\right)$ with synthetic terminal liquor was measured using a solution calorimeter. Values at $70^{\circ} \mathrm{C}$ for the calcined kaolin were significantly higher than for the uncalcined clay. The reaction with uncalcined kaolin was also slower and more complex than with calcined kaolin. At least three reaction steps were observed for uncalcined kaolin: adsorption of solution by the clay, destruction of the clay crystal structure, and crystallization of the cancrinite product.

Although previous work on the kinetics of claywaste reactions was confined to uncalcined clays, calcined 
clays (clays heated to $\sim 7.00^{\circ} \mathrm{C}$ ) have yielded superior products when reacted with waste solutions. These products have lower volumes, are harder, and will not crumble when contacted with water. Calcined clays react 5 to 30 times faster with standard waste solution than do uncalcined clays. Half-times for the calcined kaolin reactions at $100^{\circ}, 75^{\circ}$, and $50^{\circ} \mathrm{C}$ are $<0.2,0.7$, and 4 hours, respectively.

Previous reports have stated that leach rates of aqueous silicate products in distilled water are in the range $10^{-8}$ to $10^{-7} \mathrm{~g} / \mathrm{cm}^{2}$ day, based on cesium. Such leach rates were based on the B.E.T. method of measuring surface. area which measures every pore and surface which can be reached by gas molecules. In a porous matrix such as a powder this can be a very large area $\left(10^{4}-10^{5} \mathrm{~cm}^{2} / \mathrm{g}\right)$. However leach rates based on a B.E.T. surface are difficult to use in determining the radionuclide release from a storage matrix (stored nuclides in the form of a 55-gallon drum for example), where only the geometric surface area can be measured. Since the various engineered storage modes will influence the choice of the final waste form and shape, immediate conversion to a geometric base for determining leach rates will minimize ambiguities and conversion errors when extrapolating laboratory data into a full-scale process.

Care must be exercised in making this transition since leach rates will appear to increase depending on the B.E.T. surface-to-geometric surface ratio. This is not the case--the increase is due only to a change in the bases for the calculation; $e . g .$, leach rates based on B.E.T. surface area could be $10^{-8} \mathrm{~g} / \mathrm{cm}^{2}$-day; the same data based on a geometric area would be $10^{-5} \mathrm{~g} / \mathrm{cm}^{2}$-day using cancrinite as a 
reference material.

Binders are needed to convert the small cancrinite crystals into a massive form which can be conveniently handled and stored. Tests indicated that sodium silicate solution combined with various curing agents gives a hard, strong, water-resistant binder. Curing agents studied thus far are sodium fluorosilicate, portland cement, and zinc oxide. Zinc oxide appears to yield the most water-resistant binder.

Tests of mechanical stability of aqueous silicate products in water showed that, in general, products made from calcined kaolins and bentonites endure well under water, as do nepheline products made by firing the cancrinite aqueous silicate product. Conversely, products made from uncalcined clays (especially uncalcined bentonites) mechanically disintegrate when soaked in water.

\section{Evaluation of Effort}

The laboratory work which will serve as a basis for design of a prototype Aqueous Silicate process has been virtually completed. This study has indicated several different conceptual pathways by which solidification of recycle liquor is possible.

\section{Future Work}

The heat of reaction of calcined and uncalcined bentonite will be determined and inorganic and organic. binders will be further evaluated. The fate of significant radioisotopes, such as ${ }^{137} \mathrm{Cs},{ }^{90} \mathrm{Sr},{ }^{106} \mathrm{Ru},{ }^{99} \mathrm{Tc}$, and ${ }^{125} \mathrm{Sb}$, in the formation of cancrinite will be determined. 
Characterization of Waste Tank Salt Cake

Project Managers:

Principal Investigators:
R. C. Roal

H. Babad

N. L. Harms

M. J. Kupfer

J. S. Buckingham

D. G. Bouse

M. D. Martin

V. L. Schuelein

W. I. Winters

S. J. Johnson

R. E. Van der cook

Objective and Scope

In this program tests will be developed to characterize waste tank salt cakes and to identify conditions necessary to form a stable solid. Elements of equipment for sampling and analyzing salt cakes will be identified, the thermal properties of the salt cakes will be measured, and an analytical method for analyzing actinides in the salt cake will be developed.

\section{Prior Work}

Analytical techniques and procedures were established to measure major chemical and physical properties of waste salt cake. Engineering and laboratory studies indicated that sampling and handing equipment should be redesigned.

Progress During Report Period

Salt samples from selected 242-s slurry receiving tanks were partially characterized with the following results: 
CHARACTERIZATION OF 242-S SALT

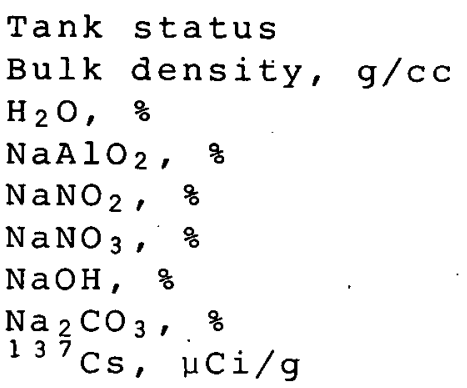

$\begin{array}{ccccc}105-S & & 106-S & 109-5 & 111-S \\ \text { Drained } & \text { Active } & \text { Active } & \text { Active } \\ 1.26 & 1.27 & 1.10 & 1.70 \\ 3 & 4 & 9 & 17 \\ 0 & 1 & 1 & 2 \\ 0 & 0 & 0 & 2 \\ 94 & 90 & 85 & 63 \\ 0 & 1 & 2 & 6 \\ 2 & 4 & 3 & 10 \\ 8.9 & 17.2 & 56 . & 96 .\end{array}$

Salt from Tank lll-s deliquesced in six days when placed in an $80 \%$ relative humidity atmosphere at $23^{\circ} \mathrm{C}$. Under the same conditions, salt from Tank 109-S deliquesced in 23 days and salt from 106-s in 25 days, while salt from 105-S had not deliquesced in 30 days.

Two solvent extraction procedures for separating actinides from Hanford waste are being examined. Undiluted dihexyl-N, N-diethylcarbamylmethylenephosphonate (DBDECMP) was found to quantitatively extract ${ }^{24} \mathrm{Am},{ }^{239} \mathrm{Pu},{ }^{2{ }^{37} \mathrm{~Np}}$, and ${ }^{233} \mathrm{U}$ from synthetic waste that had been acidified to $6 \mathrm{M}$ $\mathrm{HNO}_{3}$. Initial tests indicate actinides may be stripped from DHDECMP diluted with xylene; however further work is needed to define parameters for extracting and stripping actinides from 100\% DHDECMP. Aliquat-336 (General Mills Company), a quaternary amine, quantitatively extracts ${ }^{239} \mathrm{Pu},{ }^{237} \mathrm{~Np}$, and ${ }^{2}{ }^{3} \mathrm{U}$ from synthetic waste acidified to between 3 and $4 M$ $\mathrm{HNO}_{3}$. Americium-24I can be extracted into Aliquat-336 after the acidified waste is neutralized to $\mathrm{pH} 2$. Plutonium, Np, and $\mathrm{U}$ were stripped from the organics with $1 M \mathrm{Na}_{2} \mathrm{CO}_{3}$ and $\mathrm{Am}$ was stripped with $8 \mathrm{M} \mathrm{HNO}_{3}$.

Thermal conductivity measurements were made on solid samples from 10 waste storage tanks and on 7 samples 
of Tank Farm backfill material. Equipment was installed in the 222-S Building Room 1-A hot cell for this purpose. Thermal conductivities for the waste storage tank samples ranged from a low of 0.144 watts/meter- ${ }^{\circ} \mathrm{C}$ (on a sample from Tank 107-S measured at $201^{\circ} \mathrm{C}$ ) to a high of 1.848 watts/ meter- ${ }^{\circ} \mathrm{C}$ (on a damp sample from Tank 102-SX measured at $\left.23.1^{\circ} \mathrm{C}\right)$. Thermal conductivities of Tank Farm backfill materials, ranged from 0.221 to 0.886 watts $/$ meter $-{ }^{\circ} \mathrm{C}$.

\section{Evaluation of Effort}

The basis for actinide analysis of low-level salt wastes has been established. The availability of thermal conductivity measurements has made it possible to more accurately calculate heat profiles expected in salt cake.

\section{Future Work}

Analytical procedures for actinide analysis will be developed using bidentate organophosphorus and/or amine extraction. Thermal conductivities of high-level sludge samples will be measured in the 1-A hot cell. Actuail salt cake will be characterized when it becomes available:. 
PUBBLIC PROTECTION ASSURANCE

Waste Cleanup and/or Immobilization

$\begin{array}{ll}\text { Project Managers: } & \text { R. E. Isaacson } \\ & \text { D. A. Turner } \\ & \text { A. J. Shuckrow (BNW) } \\ & \text { R. L. Dillon (BNW) } \\ \text { Coordinating Engineer: } & \text { L. E. Bruns } \\ \text { Principal Investigators: } & \text { K. T. Key } \\ & \text { W. W. Schulz } \\ & \text { N. J. Englund (BNW) } \\ & \text { R. C. Arnett (BNW) } \\ & \text { P. L. Koehmstedt (BNW) } \\ & \text { B. W. Mercer (BNW) } \\ & \text { E. M. Woodruff (BNW) }\end{array}$

Objectives and Scope

In this program new methods for cleanup and/or stabilization of radioactively contaminated surface and subsurface soils will be developed. For both surface and subsurface areas the procedure will be as follows: characterization of the radionuclides in the soil; hazard assessment; establishment of cleanup criteria; and identification of adequate cleanup and/or immobilization methods.

Work on subsurface contaminated volumes (such as cribs, trenches, and buried ponds). will initially concentrate on stabilization in situ. Technology will be developed either to affix contaminated areas or volumes in situ or remove the contaminated soil and affix and/or package the waste for storage or disposal.

\section{Prior Work}

Initial "cold" field tests demonstrated that the prototype mobile vacuum system could effectively remove surface contaminated soil. A grouting field test was carried out in a Tank Farm well to study the effectiveness of 
AM- (American Cyanamid Company) gel interspersed in soil as a second seal of a high-level waste tank. In-field well grouting tests demonstrated that waste tanks within 6' of the wells could be subjected to pressures about 10 psig. Initial laboratory well-grouting tests demonstrated that an asphaltic or asphaltic-cement grout may be superior to a cement grout.

\section{Progress During Report Period}

Vacuum cleaner prototype tests were deferred to calendar year 1975. A design of a water spray system for the prototype was completed and necessary equipment procured. Initial work began on testing sock filter efficiency.

A 16 cubic yard vacuum system was demonstrated on the BC Crib area by Power Master of Portland, Oregon. Cleanup capacity for a simulated sparsely contaminated zone was estimated at four to eight acres per day, or about the capacity of the prototype unit (which has a $6 \mathrm{yd}^{3}$ capacity). Four 4" hoses were operated from the Power Master unit, as compared with two from the prototype.

In situ soil affixing and well-grouting techniques were simulated in the laboratory. In the soil-affixing studies various mixtures of a $65 \%$ asphaltic emulsion and water were used with soil and extruded under pressure. Cement, cement-asphalt, and asphaltic emulsions were used as well-grouting agents. Laboratory studies also included treatment of high-level waste terminal liquor with clays, followed by addition of asphaltic emulsion to reduce leach potential.

Additional pond cleanup methods were investigated while pond use continued.' Scope flowsheets were devised and discussions were held with several equipment vendors. A 
tentative flowsheet calls for dredging (or mudcatting) the pond, followed by use of solids-liquid separation devices, a mobile clarifier, and a series of cyclones. The water returns to the pond and the sludge goes to an underground $V-$ trench with impenetrable asphalt-soil-fixed sides.

The distribution of particle sizes in a representative sample of $U$ Pond bottoms was determined electrically using a High Accuracy Product Corporation Automatic Particle Counter. The diameters of all the particles in the particular soil sample tested were greater than 10 micrometers; approximately $34 \%$ of the particles had diameters in the range 15 to $25 \mu \mathrm{m}$.

\section{Evaluation of Results}

- The six-cubic-yard prototype-vacuum needs a water spray system to minimize dusting when unloading and assure that solids which pass through the filter are not harmful. The prototype unit has sufficient capacity to handle relatively small areas (such as an acre of two or along fences). It may be necessary to have one or more big units $(e . g ., 12$ to $16 \mathrm{yd}^{3}$ ). to handle large areas like the overall BC Crib. It is felt that for large areas vacuuming would be better than blading since blading removes organic matter (which takes many years to rebuild) and is destructive to plant life. Hoses of the greatest possible length should be used to minimize destruction of vegetation.

Particles in U Pond bottoms have diameters large enough to permit use of a Mud Cat(R) (National Car Rental . system, Inc.), dredge, or similar solid-liquid separation equipment to separate soil from associated liquor. It appears that pond bottoms can be removed at reasonable cost and that ground affixation could possibly be considered as a 
disposal technique.

Use of an asphaltic emulsion for grouting around wells and soil affixation appears promising. Historical data indicate a life-time for such solidified mixtures of 5000 years or more as long as they are below the frost level in the subsurface. Additional laboratory work is needed to optimize the affixing agent and the amounts to be used.

\section{Future Work}

The vacuum system will be tested for particle size throughput and a spray system will be installed and tested. A $16 \mathrm{yd}^{3}$ system with boom will also be tested.

Well-grouting studies will continue to optimize the alphaltic emulsion grout mixture for all soil conditions. A "cold" test is planned on subsurface soil affixation in cooperation with the Waste Management and Transportation long-range program. Studies will continue on affixing clayhigh-level waste mixtures with asphalt.

If funding permits, a dredge and Mud Cat will be tested on a "cold" pond. Work with offsite vendors will continue.

An elutriation test of about one acre is planned in the BC Crib area, using an ammonium nitrate solution, to see if surface activity can be moved below the ground surface. An evaluation will then be made to determine whether this technique could reduce the airborne contamination potential in the event of a range fire.

Initial scoping work will begin on equipment for removing radionuclides on a surface and affixing contamination in place. This equipment should minimize surface and airborne contamination. 


\title{
Nondestructive Measurement Instrumentation
}

\author{
Project Manager: \\ H. Babad \\ Principal Investigator: \\ W. H. Zimmer
}

\section{Objective and Scope}

In this program instrumentation will be developed which will nondestructively and automatically inventory radionuclides for sorting, accounting, and field measurement purposes.

\section{$\underline{\text { Prior Work }}$}

Two Tracor Northern, Inc., NS-600 pulse height analyzer-computers oriented to gamma energy analysis and one NS-880 oriented to X-ray range energy analysis have been placed in service. These three systems with their associated custom programs comprise the Gamma, X-Ray Data Reduction (GXDR). System. The purpose for this system is to provide all of ARHCO with automatic data reduction of gamma spectral data received on magnetic tape cassettes. Eight satellite analyzer-cassette recorders are currently producing data for GXDR system action and more systems are soon to be added.

Detector systems have been developed and are in service for gamma energy analysis of bulk environmental samples, low-level crib and tank leak soil cores, low-level air filter samples, evaporator product and effluent samples, high-level waste management research and development support, passive fissile analysis, and others.

\section{Progress During Report Period}

Due to the successful initiation of the GXDR system, the data acquisition capability of both NS-660's has 
been removed--making these units available for full-time data reduction. The older NS-600 was made a hardware twin to the newer NS-660. Routine use of the interactive data reduction capabilities of the Nuclear Data 50/50 has been discontinued, resulting in better manpower utilization and more accurate, sophisticated, automatic, and efficient gamma spectral data reduction in GXDR. New additions to the ARIS-2 (Automatic Radioactive Inventory.System) program provide a choice of three independent modes of random coincidence summing correction, allowing subtraction of the contribution of any isotopic spectrum from any peak to be data-reduced and more accurate calculation methods for precision and limits of reduction.

The NS-880 has been programmed to perform plutonium isotopic analysis on a routine basis. Final testing is dependent on the delivery of supporting detector systems.

During the report period the lithium-drifted germanium [Ge(Li)] detector system, to which all of the other gamma systems were referenced, degraded beyond a useful or recoverable range, and has been replaced. This detector and all of the detector systems in the chemical Technology Laboratory are being recalibrated in our routine biannual program.

\section{Evaluation of Effort}

The GXDR System is a resounding success, as evidenced by its ability to perform active data reduction for six satellite acquisition systems, remove the acquisition capability from the NS-660's, and retire the data reduction capabilities of the ND-50/50.

The status of acquisition systems is less impressive. A replacement mid-range $\mathrm{Ge}(\mathrm{Li})$ detectọ has been 
procured, calibrated, and placed in. service but the new very-high and very-low activity range acquisition systems have not been brought on line--due primarily to delivery delays in cable connections.

\section{Future Work}

The description and performance of the ARIS-2

program for gamma energy analysis in the GXDR System will be reported: Outputs of the four 4096 channel analyzers in the ND-50/50 will be routed through the internal PDP $9 / \mathrm{L}$ computer to the GXDR System and to an NS-11i magnetic tape cassette recorder. This will permit use of these four. analyzers for on-line data acquisition or as standard GXDR satellites.

The dual Ge(Li) primary-NaI(Ti) Compton Suppression ( $Z$ ) System for ultra-low activity gamma energy analysis and the high-activity anti-Compton (E) System will be calibrated, evaluated, and placed in service.

The prototype X-ray fluorescence system will be evaluated against the purchase specifications.for acceptance.

Inclusion of the Nondestructive Assay acquisition systems of the Process Control Laboratory at the 234-5 Building will add two more satellite units to the GXDR system.

Progress in acquisition and use of a Californium Multiplier-Subcritical Assembly directed at lowering the detection level of fission elements and activation analysis will be reported as a separate program. 
Environmental Instrumentation

$\begin{array}{ll}\text { Project Managers: } & \text { R. E. Isaacson } \\ & \text { J. H. Jarrett (BNW) } \\ & \text { R. W. Perkins (BNW) } \\ \text { Coordinating Engineer: } & \text { L. E. Bruns } \\ \text { Principal Investigators: } & \text { L. T. Key } \\ & \text { R. G. Oliver } \\ & \text { G. E. Martin } \\ & \text { W. H. Zimmer } \\ & \text { R. L. Brodzinski (BNW) } \\ \text { N. } & \text { O. Hogman (BNW) } \\ & \end{array}$

Objective and Scope

The objective of these studies is to develop instrumentation and auxiliary equipment for field use that will accurately and rapidly characterize the amount, type, and distribution of radionuclides on soil surfaces, on pond bottoms, and to root and animal burrowing depths. Whenever possible, radionuclides will be assayed in situ, and sensitivity should be in the range of picocuries per gram of soil. Auxiliary equipment to be developed or tested includes airborne particle size detectors, new types of meteorological instrumentation, updated control systems for resuspension towers, and subsurface void volume detectors.

\section{Prior Work}

Equipment [an in situ gamma Ge(Li) system, an argon millirem per year sensitive dosimeter, and a neutron counter] for Dev-Van-I, a radionuclide assay van for surfaces, was calibrated and field-tested. Basic research on ${ }^{9} \mathrm{Sr}$ and ${ }^{239} \mathrm{Pu}$ environmental in situ assayers for Dev-Van-I began. A directional neutron probe was devised and used successfully in determining the neutron flux from the $\mathrm{z}-9$ Trench floor. A wafer technique was used in the Z-9 Trench 
for determining neutron dose rate, 0.1 to $0.5 \mathrm{mrem} / \mathrm{hr}$. other instruments tested included an alpha water analyzer and a magnetometer for detecting subsurface metal. Well assay instrumentation for Dev-Van-II, the subsurface assay van, was received.

\section{$\underline{\text { Progress During Report Period }}$}

The mobile unit for Dev-Van-I was received and design work on auxiliaries and equipment installation was initiated. The alpha water monitor for. Dev-Van-I was calibrated. Field-testing with the neutron counter showed that the plutonium values on the $U$ Pond bottom surfaces were not detectable with a neutron counter. Further results were obtained with the sensitive Reuters-stokes gamma dosimeter.

Some instrumentation for Dev-Van-II was delayed at the factory. The californium in-well activation system has been deferred until fiscal years 1976 or 1977; it will require a new van, Dev-Van-III.

Determination of neutron flux by the wafer technique was continued in areas high in plutonium values (e.g., plutonium storage and processing areas); also a high-level waste tank neutron profiling was tried using copper disks.

The magnetometer was tested in a burned pipe, and with the data a computer plotting system was devised. Further work on automating resuspension systems was carried out and the equipment. was installed in the field.

An alpha monitor was devised and calibrated for initial checks on filter cloths removed from resuspension systems. The unit experienced excessive noise levels and varying background levels. The noise level was minimized by installation of an isolation transformer. 
A system for, ${ }^{0} \mathrm{Sr}$ field-assaying should be available for testing by about May 1975. In order to maximize contribution of ${ }^{9}{ }^{0} \mathrm{Sr}$ and minimize other beta-emitting isotopes, a thin, massless proportional counter with mu tiple aluminum beta absorbers was devised. Two systems have been conceived for a picocurie-level plutonium in situ assayer: one (by Battelle-Northwest) now in the calculation stage would use an X-ray system; the other (devised by the National Nuclear Corporation) consists of a special proprietary crystal sensor which is said to be 10 times more sensitive than detectors now in use.

The directional neutron counter was further tested in a plutonium crib, $\mathrm{Z}-1-\mathrm{A}$, by profiling a well drilled in the Z-1-A region. The size of the well limited the directional accuracy, although changes were noted in going from $0^{\circ}$ to $90^{\circ}$ to $180^{\circ}$ to $270^{\circ}$. The in-well directional unit consisted of a $3 / 4$ in. ${ }^{3}$ helium detector tube surrounded by moderation (polyethylene) and cadmium. A fast neutron directional unit will be field-tested at Hanford in 1975.

Special materials have been received for devising a series of thermoluminescent detectors (TLD) chips for determining dose rates in environmentally contaminated areas. Two standard NaI gamma monitoring units have been obtained and field-tested.

\section{Evaluation of Effort}

The alpha water meter should be valuable for checking any low-level liquid waste stream or pond water for alpha emitters. The system should be able to detect plutonium at the $\mathrm{MPC}_{\mathrm{w}}$ level. The low specific activity of neutrons from plutonium limits the use of neutron counters for environmental assaying; however they can detect areas 
which warrant immediate attention (levels in the $\mathrm{mCi} / \mathrm{g}$ range).

The wafer technique appears to be an excellent method for estimating plutonium concentration and neutron dose in a field high in gamma. First attempts in a waste tank showed that the sensitivity needs to be improved; this can be done by increasing the copper surface area per foot of length.

Both gamma and neutron counters have been used for profiling specific isotopic activity in crib wells. Excellent gamma profiles were noted in cribs with low activity, but cribs with higher activity "jammed" the electronics. A small (less than $1 \mathrm{~cm}^{3}$ ) $\mathrm{Ge}(\mathrm{Li})$ detector on order for Dev-Van-II should work on the higher activity crib, if properly shielded. Neutron profiles were obtained for a Puonly crib and a gamma-plus-actinide crib; however accuracy of. the latter may be questionable due to the gamma sensitivity of $\mathrm{BF}_{3}$ neutron detectors.

The wafer technique may be the best for $\mathrm{Pu}$ profiling if significant gamma is present.

\section{Future Work}

Dev-Van-I equipment will be installed and initial field-testing implemented.' Further testing will be done with the alpha water meter and reports will be written on the Reuters-stokes sensitive dosimeter and the directional neutron counter.

Dev-Van-II will be obtained, along with remaining necessary instrumentation and auxiliaries; installation design will be initiated. $\because$

The in situ beta monitor will receive initial 
testing. A. cooperative program will be undertaken with National Nuclear Corporation to develop two instruments: a directional fast neutron counter and a sensitive $\mathrm{X}$-ray monitor for in situ plutonium assaying.

A series of TDL, using different compounds and shielding, will be devised, calibrated, and placed in key locations in the 200 Areas plateau for dose studies. The sensitivities of wafer techniques will be improved in an effort to obtain reliable plutonium profiles in high-level waste tanks.

While efforts to perfect the filter cloth alpha monitor continue, work will begin on a gamma monitor. Equipment for detecting subsurface void volume will be investigated further. If funds permit, the Holosonics transfer impedance system will be tested. Initial work on a $252 \mathrm{Cf}$ in situ activation sy'stem will consist of studying. various concepts and consulting with BNW and Intelcom on an optimum concept.

Methods for analyzing $\mathrm{Pu}$ content. in waste barrels at the $10 \mathrm{nCi} / \mathrm{g}$-level will be investigated in the next six months. 
Waste Characterization

$\begin{array}{ll}\text { Project Managers: } & \text { R. E. Isacson } \\ & \text { L. C. Schwendiman (BNW) } \\ & \text { L. L. Wendell (BNW) } \\ \text { Coordinating Engineer: } & \text { L. E. Bruns } \\ \text { Principal Investigators: } & \text { K. T. Key } \\ & \text { W. W. Schulz } \\ & \text { T. W. Horst (BNW) } \\ & \text { J. Mishima (BNW) } \\ & \text { M. M. Orgill (BNW) } \\ & \text { G. A. Sehmel (BNW) } \\ & \text { R. K. Woodruff (BNW) }\end{array}$

Objectives and Scope

This program identifies the locations, the physical and chemical properties, and the means by which radionuclides at Hanford can enter man's environment: The characerization studies are limited to the 200 Areas Plateau and consider movement of radionuclides as a result of meteorological and biological driving forces.

\section{Prior Work}

About $500 \mathrm{U}$ Pond analyses were received in the DEBR/ARHCO programs, including plutonium and americium concentrations in organisms and pond bottoms. Initial chemical and physical properties studies of the actinides in the Pond bottoms began. Further samples of contaminated surface materials were collected around 'U Pond.

The surficial distribution of $1{ }^{37} \mathrm{Cs}$ in the $\mathrm{BC}$ control area was characterized and reported. Studies of the airborne release of ${ }^{137} \mathrm{Cs}$ from surficial-contaminated materials involved in a fire and from the solid residues were completed.

Plutonium released in the gaseous effluent from $\mathrm{Pu}$ operations was characterized and the sampling system 
evaluated. Automated air sampling became operational:

U Area and some other sites were identified as sources of airborne radioactivity, although all airborne concentrations have been far below the MPCair for occupational exposure.

Flow fields and air trajectories determined by a new computer program were determined to be superior to those computed from a point source, especially for distances greater than a few kilometers downwind. A diffusion model for estimating airborne contaminants was adapted, and a study of resuspension of contaminated particulates by winds and dust devils was initiated.

Redox swamp areas were assayed for sources of radionuclides, as was the bottom layer of Gable Mountain Pond.

Leak detection systems from Boeing Aerospace Corporation, Battelle-Northwest, and Holosonics were tested. Results favored further testing of the Boeing and Battelle systems (see "External Leak Detection," p. 64).

\section{Progress During Report Period}

Surficial contaminated materials from the BC Crib and $U$ Pond areas were sampled and heated. Resuspensions were generally low.

A computer model which considers deposition and diffusion parameters was applied to calculate the downwind airborne concentrations of ${ }^{13^{7}} \mathrm{Cs}$ from the $\mathrm{BC} \mathrm{Crib}$ at various distances and heights. The study showed that the distribution of resuspended contaminated material from soil is a function only of the ratios of the resuspension rate-toaverage wind speed and deposition velocity-to-average wind speed. 
Resuspension experiments, with respect to a selected speed range and a set direction, were conducted at the $\mathrm{U}$ Pond and $\mathrm{BC}$ Crib areas. The concentrations of ${ }^{13^{7} \mathrm{Cs}}$ downwind from $U$ Pond have been below MPCair but consistently higher than at the $B C$ site by a factor of about five.

A computer model for determining trajectories and concentrations of airborne material from the $\mathrm{BC}$ Crib area or other release points on the 200 Areas Plateau was further developed. This windfield model demonstrated that computergenerated trajectories and concentration patterns are more realistic and reliable than those computed from source winds only.

Dust devil frequency during the summer was studied and temperature conditions conducive to dust devil formation were analyzed. Dust devils were the subject of a literature study.

Representative sampling studies of surficial areas and cores continued with development of techniques for composite surface ( $r i n g$ ) and core sampling to depths of $30 \mathrm{~cm}$. Samples were prepared by ARHCO and BNW and analyzed by the LFE Laboratory of Richmond, California, BNW, and ARHCO. Some initial interlaboratory results were obtained for reliability checks.

Work continued on determination of physical and chemical properties of environmental radionuclides. Particle sizes of $U$ Pond sediments were determined and leachability of plutonium from U Pond sediments was reported.

In cooperative programs with the Division of Biochemical and Environmental Research, further results were obtained on analyses of aquatic organism buildup in $U$ Pond sediments. Initial samples were taken on Gable Mountain 
sediments and aquatic organisms.

surface (ring) and core (30-cm deep) samples were taken in the Redox swamp and ditch as an initial characterization, step.

Initial characterization studies of cribs were conducted using nondestructive instruments for profiling radionuclides via dry wells. Both gamma and neutron measurements were made.

Approximately 25 detonation tests were conducted at Stanford Research Institute (SRI) using mixtures of . simulated salt cake and anion exchange resin. A report was issued on the toxicity of the elements and a simplified computer program was developed for estimating the hazard index of any radioactive waste entity.

\section{Evaluation of Effort}

Understanding of local atmospheric-surface interactions has been furthered by these investigations. Resuspension studies give assurance that only a small fraction of radioactivity is resuspended each year from the $\mathrm{BC}$ Crib and $U$ Pond areas, and also indicate the existence of sources other than the immediate areas of concern.

The computer models of resuspension and transport have permitted a factual assessment of downwind airborne concentrations. The ability to plot trajectories and downwind concentrations of particles, taking into account changing windfields and diffusion coefficients as measured by several stations, provides a valuable tool in airborne hazard assessment.

Representative samples of surficial areas and cores from the same area and sample preparation techniques 
have indicated that the sampling method is reasonably representative and that aliquots taken from the prepared samples are in good agreement when analyzed. Interlaboratory results to date show good agreement with ${ }^{137} \mathrm{Cs}$, but some ${ }^{90} \mathrm{Sr}$ résults have shown differences of 2- to 25-fold.

More data are required on physical and chemical properties before initial conclusions can be made about the significance of any specific property in pathways to man. The cooperative programs of DBER and ARHCO have resulted in benefits that far exceed the expectations of any. individual program.

Crib profiling with nondestructive-type instrumentation has identified relative concentrations with height for ${ }^{137} \mathrm{Cs},{ }^{2}{ }^{39} \mathrm{Pu}$, and total gamma.

In detonation experiments at SRI on mixtures of simulated salt cake and resin, no detonation resulted. Further study indicated that worst cases were not attained (higher oxidation-agent concentration is possible) and the small-size samples used for the tests may not be representative of in-tank conditions.

\section{Future Work}

The studies of resuspension in the $\mathrm{BC}$ Crib and $U$ Pond areas should make it possible to determine resuspension rates for the various contaminated areas for the range of conditions of interest and the particle size distribution. The z-9 Trench as a resuspension source and the releaise of stored high-level waste (salt cake) will be investigated. Surficial contamination of $U$ Pond will be characterized and data on its release in fires will be generated. The influences of local topography and the extension of the transport diffusion model beyond $10 \mathrm{~km}$ will 
be incorporated in future models in order to establish a reliable representative wind network to provide real time data. A document on dust devils and anomalous winds will be issued.

\section{Efforts will continue to firm up methods for} attaining representative samples, inproving sample preparation, and obtaining reliability of environmental laboratory analyses.

Physical and chemical property studies of actinides in the pond bottoms will continue in the next year with an increased effort.

Process Technology status reports on the BC Crib area, U Pond, and the Redox Swamp-Ditch will utilize characterization methods developed by this program.

Initial characterization work with Dev-Van-I, a mobile unit capable of analyzing the soil surface, will begin.

Detonation tests conducted at SRI will use 6"rather than 2"-diameter charges and higher concentrations of oxidizing agent. Some Le Granyian tests, which can record instantaneous temperature and pressure changes during detonation or deflagration, are also planned. A Hazard Index report will be issued.

\section{Reports. Issued}

L. E. Bruns and S. R. Weil, "Directional Neutron. Flux Survey of Actinide Waste Trench," ANS Transactions, Vol. 18, June 1974, pp. 5253. 
WASTE TANK LEAK DETECTION AND PREVENTION

Waste Tank Liquid Level Monitoring System

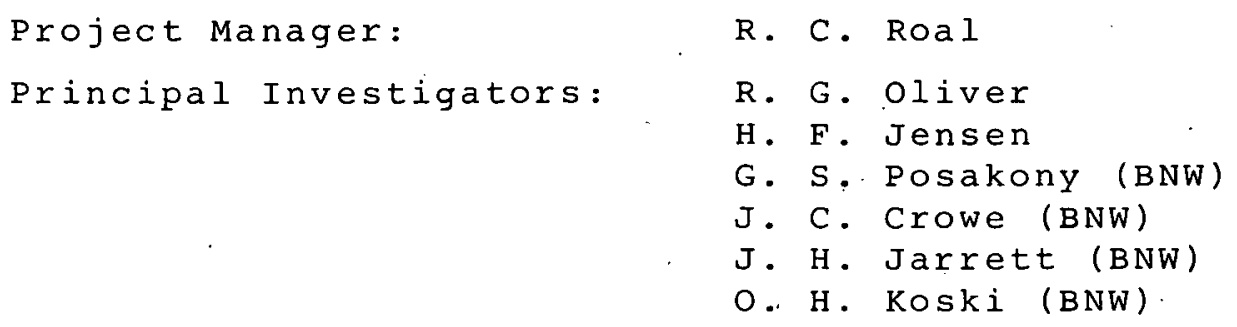

Objective and scope

This program consists of two phases. The first part, which has been completed, was an engineering audit of the present liquid level monitoring system. The remainder. of the program will review and develop improved means of determining liquid levels in radioactive waste storage tanks.

\section{Prior Work}

Different methods of monitoring liquid level were investigated and a radiofrequency-absorption type and ultra-. sonic log concept were selected for more detailed study.

A laboratory test of a modified radio-frequency liquid level system problem configuration showed that this monitoring device greatly increased the capacitive impedance and resulted in a lower temperature coefficient, better linearity, and greater insensitivity to liquid conductivity-but at the expense of sensitivity. Sensitivity was, however, several magnitudes better than required for an acceptable system. Composition variation in the liquid phase from tap water to $4 M \mathrm{NaNO}_{3}$, and saturated $\mathrm{NaNO}_{3}$ showed no appreciable effects. Voltage supply variations from 100 to 150 volts at $60 \mathrm{~Hz}$ also showed no short-term effects on the output. 
Ultrasonic impedance and attenuation measurements made on simulated wastes indicated that although liquid wastes are slightly weaker transmitters of ultra-sound than water, there should be. no significant problem in transmitting ultra-sound through the liquid waste over reasonable distances. (10' to 15'). Ultrasonic attenuation measurements were also made on simulated salt cake with laboratory test apparatus. Although the salt cake material weakened the signal even more than the liquid waste material, a useful ultrasonic signal could be transmitted. These measurements will be used for determining the transmitter pulse power requirements for the demonstration model of the ultrasonic logging system.

\section{Progress During Report Period}

The entire breadboard ultrasonic logging system, including the transducers, positioning mechanisms, and electronics package, was tested under simulated waste tank conditions.

The ultrasonic logging and the radiofrequency (RF) measurement systems were installed in a tank containing an FIC (Fruit Industries Corporation) gauge. This will allow comparison of the three measurement systems under dynamic in-tank conditions.

A preliminary design concept has been established for the electronics portion of the prototype ultrasonic logging system. The concept provides for data storage at each tank location through the use of semiconductor memory devices.

An RF impedance liquid-level detection system was tested to determine the basic long-term stability of the system. The tests disclosed that a cyclic variation of \pm 50 
parts out of a basic range of $10^{5}$ units results from the particular temperature control system being used.

Evaluation of Effort

The ultrasonic logging and $R F$ impedance systems appear to be acceptable methods for measuring liquid level in the waste storage tanks.

\section{Future Work}

The fabrication of demonstration units of both systems will be completed and in-tank testing should be completed by the end of the next report period. 
Waste Tank Integrity

Project Managers:

R. E. Isaacson

R. C. Roal

Principal Investigators:

R. F. Maness (BNW)

E. L. Moore

\section{Objective and Scope}

As one objective this program will attempt to identify tank failure mechanisms and methods for predicting imminent tank failures. Additionally, the feasibility of extending tank life by cathodic protection will be investigated.

\section{$\underline{\text { Prior Work }}$}

Concentration cells in alkaline high-level waste were evaluated as a cause of localized attack of mild steel. Voltage measurements on mild-steel coupons immersed in airfree and air-sparged $6 \mathrm{M} \mathrm{NaOH}$ solutions at $90^{\circ} \mathrm{C}$ indicated an ennobling effect of about 100 milivivols as a result of the air sparge. Cells produced by immersing mild-steel electrodes in concentrated versus dilute $\mathrm{NaOH}$ and $\mathrm{NaOH}-\mathrm{NaNO}_{3}$ versus $\mathrm{NaOH}\left(\right.$ all at $90^{\circ} \mathrm{C}$ ) were found to be of little or no consequence. Attempts to produce preferential attack of mild steel at the liquid-vapor interface in air-sparged simulated alkaline high-level waste solution were not successful. General corrosion and pitting attack in the vapor phase were accelerated as a result of the air sparge, whereas attack in the liquid phase was inhibited.

The corrosiveness of Hanford high-level radioactive waste is reduced by the presence of the nitrite produced by the radiolytic decomposition of nitrate. The effect of a large dilution of high-level waste solution on mild-steel corrosion was determined by exposing mild-steel 
specimens to dilute salt solutions containing six levels of nitrite in the range 0.1 to $0 M$. Three solution compositions were used, all at pH 9.5: (1) $0.01 M \mathrm{NaNO}_{3}-0.1 \mathrm{M} \mathrm{Na}_{2} \mathrm{SO}_{4}$, $0.01 \mathrm{M} \mathrm{NaNO}_{3}-0.05 \mathrm{M} \cdot \mathrm{Na}_{2} \mathrm{SO}_{4}$, and (3) $0.05 \mathrm{M} \mathrm{Na}_{2} \mathrm{SO}_{4}$. Specimens were exposed at $25^{\circ}$ and $60^{\circ} \mathrm{C}$ for 325 hours. Pitting and crevice attack occurred in the nitrate-bearing solutions at $25^{\circ} \mathrm{C}$ with nitrite concentrations of $10^{-2}$ and $10^{-1} \mathrm{M}$. No pitting or crevice attack occurred at higher or lower nitrite concentrations. In the sulfate solution, pitting and crevice attack occurred at nitrite concentrations of $10^{-2}$ and $10^{-1} \mathrm{M}$. At $60^{\circ} \mathrm{C}$ the range of pitting included nitrite concentrations from $10^{-5}$ to $10^{-1} \mathrm{M}$. Penetration during the test period ranged from about 3 to 10 mils.

Mild-steel specimens cathodically protected in simulated solidified waste were examined after 1850 hours of exposure to a waste containing $15 \%$ excess water at $85^{\circ} \mathrm{C}$; current densities were 2.5, 5.0, and 10 milliamps per square foot. The specimens exposed to current densities of 2.5 and $5.0 \mathrm{~mA} / \mathrm{ft}^{2}$ corroded at rates of 1 to $2 \mathrm{mils}$ per year as evidenced by weight loss. However pitting attack was rather severe ( $25 \mathrm{mil}$ penetration) in both cases. The specimen .exposed to a current density of $10 \mathrm{~mA} / \mathrm{ft}^{2}$ showed no pitting attack and corroded at a rate of $0.8 \mathrm{mils} / \mathrm{hr}$ as determined by weight loss, indicating that the minimum protective current density lies between 5 and $10 \mathrm{~mA} / \mathrm{ft}^{2}$.

Progress was made in development of special ultrasonic needle probes which can locate cracks that fully penetrate waste tank walls. The probes require no liquid couplant and provide a rapid assessment of tank integrity.

\section{Progress During Report Period}

The probable current distribution in a 
cathodically-protected waste storage tank as a function of the number of anodes used and their placement is being determined. Data were obtained using a flat-bottomed 2'diameter mild-steel tank in the as-fabricated condition containing a dilute $0.01 \mathrm{M} \mathrm{NaOH}-0.01 \mathrm{M} \mathrm{NaNO}_{3}-0.01 \mathrm{M} \mathrm{NaNO}_{2}$ solution $(25 \mathrm{ohm}-\mathrm{cm})$. Stainless steel anodes (1/8" diameter) were used and the average cathodic current density was held constant at $10 \mathrm{~mA} / \mathrm{ft}^{2}$. Before the application of a polarizing current the potential of the tank was $-260 \mathrm{mV}$ (versus standard cell electrode) at all positions. The poorest current distribution was obtained with a single central anode and the best with six equally spaced anodes 4 " from the side and 2" from the bottom.

Instantaneous corrosion rates obtained in dilute sulfuric acid ( $\mathrm{pH} 2$ ) with a three-electrode corrator $(\mathbb{Q}$ (Petrolite Corporation) probe agreed well with the average corrosion rate obtained with the corrosometer $B$ (Magna Corporation) probe and with weight loss-correlated rate data obtained with coupons.

Tests were carried out in which mild-steel crevice specimens were exposed to aliquots of simulated solidified waste which contained between 0 and $15 \%$ nitrite. The waste, which contained $15 \%$ excess water, was held at $60^{\circ} \mathrm{C}$ in polyethylene containers. After 2700 exposure hours the corrosion rate of all specimens was about $20 \mathrm{mils} / \mathrm{yr}$ as determined by weight loss. Pitting and crevice attack appeared to be essentially independent of the nitrite content. Mild-steel coupons exposed to simulated solidified waste in sealed mild-steel containers at $60^{\circ}$ and $90^{\circ} \mathrm{C}$ were examined after 22 exposure months. Corrosion rates as evidenced by weight loss ranged from 0.7 to $4.7 \mathrm{mils} / \mathrm{hr}$. The maximum pit depth observed was 20 mils. 
The sensitivity and defect detection capability of the "point probe" ultrasonic inspection system has been improved. Laboratory tests with the point probes indicate that stress corrosion cracks in steel plate can be detected through the 1/4" thickness of asphalt-impregnated felt material between the concrete encasement and the steel tank wall.

\section{Evaluation of Effort}

Laboratory tests indicate that in a homogeneous salt system, cathodic protection could significantly reduce the tank corrosion rate. However a better understanding of the existing waste salt cake is required before an evaluation can be made on whether further development is warranted.

The use of corrosion probes appears to offer promise as a means of monitoring waste tank steel liner corrosion.

Tests showed that crevice and pitting corrosion of steel specimens is independent of the nitrite concentration in a waste:

The sensitivity and defect detection capability. of an ultrasonic needle probe has been improved.

\section{Future Work}

Studies of the corrosion of mild-steel tank liners will continue and corrosion probes will be evaluated intank. 
External Leak Detection

$\begin{array}{ll}\text { Project Manager: } & \text { R. C. Roal } \\ \text { Principal Investigators: } & \text { J. C. Crowe } \\ & \text { H. F. Jensen } \\ & \text { R. G. Oliver } \\ & \text { O. H. Koski (BNW) }\end{array}$

\section{Objective and Scope}

The current leak detection system for the underground storage tanks consists of 500 vertical dry wells around the tank and 45 laterals beneath 13 of the tanks. These are monitored for radioactivity at least once a week by gamma radiation logging equipment.

The objective of this task is to develop an improved external detection system. Such a system would permit earliex detection of smaller leaks and would, therefore, minimize the volume of leaked liquid.

Prior Work

A number of potential methods for waste tank well surveillance were studied. Since only sensitivity to changes in radiation level is required, several of the simplest systems were considered. The feasibility of an inplace radiation alarm was studied and appears suitable.

Two concepts were developed for improved waste tank leak detection resolution based upon changes in electrical impedance and resistivity of soil due to increased fluid content. In the resistivity concept, low frequency $A C$ voltage is impressed upon external electrodes surrounding the waste tank. Using available soil electrical transmissivity data, calculations indicate a leak detectability at tank bottom midpoint of 250 gallons and at tank periphery of 100 gallons. The Special Instrumentation Group of the 
Boeing Company was engaged to determine the optimum AC voltage using soil samples from tank bottom depths and to provide necessary instrumentation for a field test.' Soil electrical transmissivity tests, the field test design, and the acquisition of needed instrumentation were completed.

Soil impedance tests have been quite satisfactory and additional test applications are scheduled to further verify the results.

\section{Progress During Report period}

A proof-of-principle field test was completed in which detection methods were based upon changes in soil transmissivity and soil dielectric characteristics. Both systems exhibited the capability to detect small quantities of fluids injected into selected test site well casings.

In order to demonstrate actual Tank Farm application of the soil conductivity system, a leak detection system was installed and tested in a portion of the 241-BX Tank Farm. Circuit components and field potential circuits connecting tanks with wells in the vicinity gave satisfactory sensitivity and detection response.

Test leaks were installed from wells adjacent to Tanks 110-SX, 113-SC, and 114-SX to determine the soil resistance from well-to-well and tank-to-wells. The resistances are typically an order of magnitude lower than observed in the tank leak simulation field tests.

Capacitance values are, in general, higher than noted in the field tests. Short-circuit. currents for the various circuits were in the milliamp range for the leaked tank and from 10 to 100 microamps for the suspected and sound tank. Similar tests have been performed in 241-BX and 241-C Tank Farms. 


\section{Evaluation of Effort}

Test applications indicated the potential use of both resistivity and impedance of the soil as an early warning of changes which may be attributable to a tank leak. Additional experience is needed to generate sufficient confidence in this concept.

\section{Future Work}

Testing will continue to further identify the potential of soil conductivity measuring devices and to provide a design and operational concept for monitoring of underground transfer lines, diversion pits, and other waste handling components. 


\section{DISTR I BUT I ON}

\section{Number of Copies}

Battelle Pacific Northwest Laboratories

T. W. Ambrose

E. L. Alpen

R. E. Burns

N. E. Carter

L. C. Counts

R. L. Dillon

J. R. Eliason

J. W. Finnigan

R. F. Foster

J. J. Fuquay

J. H. Jarrett

R. E: Nightingale

D. E. Olesen

A. M. Platt

W. H. Rickard

L. C. Schwendiman.

A. J. Shuckrow

C. L. Simpson

W.G.N. Slinn

H. H. Van Tuyl

B. E. Vaughn

R. E. Wildung

R. K. Woodruff

United Nuclear. Industries, Inc.

W. M. Mathis

N. R. Miller

U. S. Energy Research and Development Administration Technical Information Center; Oak Ridge, TN

U. S. Energy Research and Development Administration, Richland Operations office

O. J. Bennett

O. J. Elgert (14)

R. M. Poteat 
DISTRIBUTION (continued)

Number of Copies

Atlantic Richfield Hanford Company

H. Babad

G. E. Backman

G. S. Barney

E. W. Bartlett, Jr.

D. G. Bouse

D. E. Braden

L. I. Brecke

D. J. Brown

L. E. Bruns

J. S. Buckingham

R. A. Deju

C. H. Delegard

D. A. Dodd

J. Faulhaber

R. E. Felt

R. D. Fox (2)

R. G. Geier

R. E. Gephart

N. L. Harms

W. M. Harty :

H. H. Hopkins, Jr.

R. E. Isaacson

H. F. Jensen

L. M. Knights

M. J. Kupfer

D. C. Lini

C. W. Malody

T. R. McKenzie

E. L. Moore

G. A. Nicholson

G. C. Oberg

R. G. Oliver

J. V. Panesko

S. M. Price

W. H. Price

D. A. Puryear

R. C. Roal

V. L. Schuelein

W. W. Schulz

H. P. Shaw

R. M. Smithers

G. T. Stocking 


\section{DISTRIBUTION (continued)}

\section{Number of Copies}

Atlantic Richfield Hanford Company (continued)

C. P. Sutter

J. H. Warren

W. I. Winters

D. D. Wodrich

W. H. Zimmer

ARHCO Document Services (2)

Extra (8) 